Historic, archived document

Do not assume content reflects current scientific knowledge, policies, or practices. 


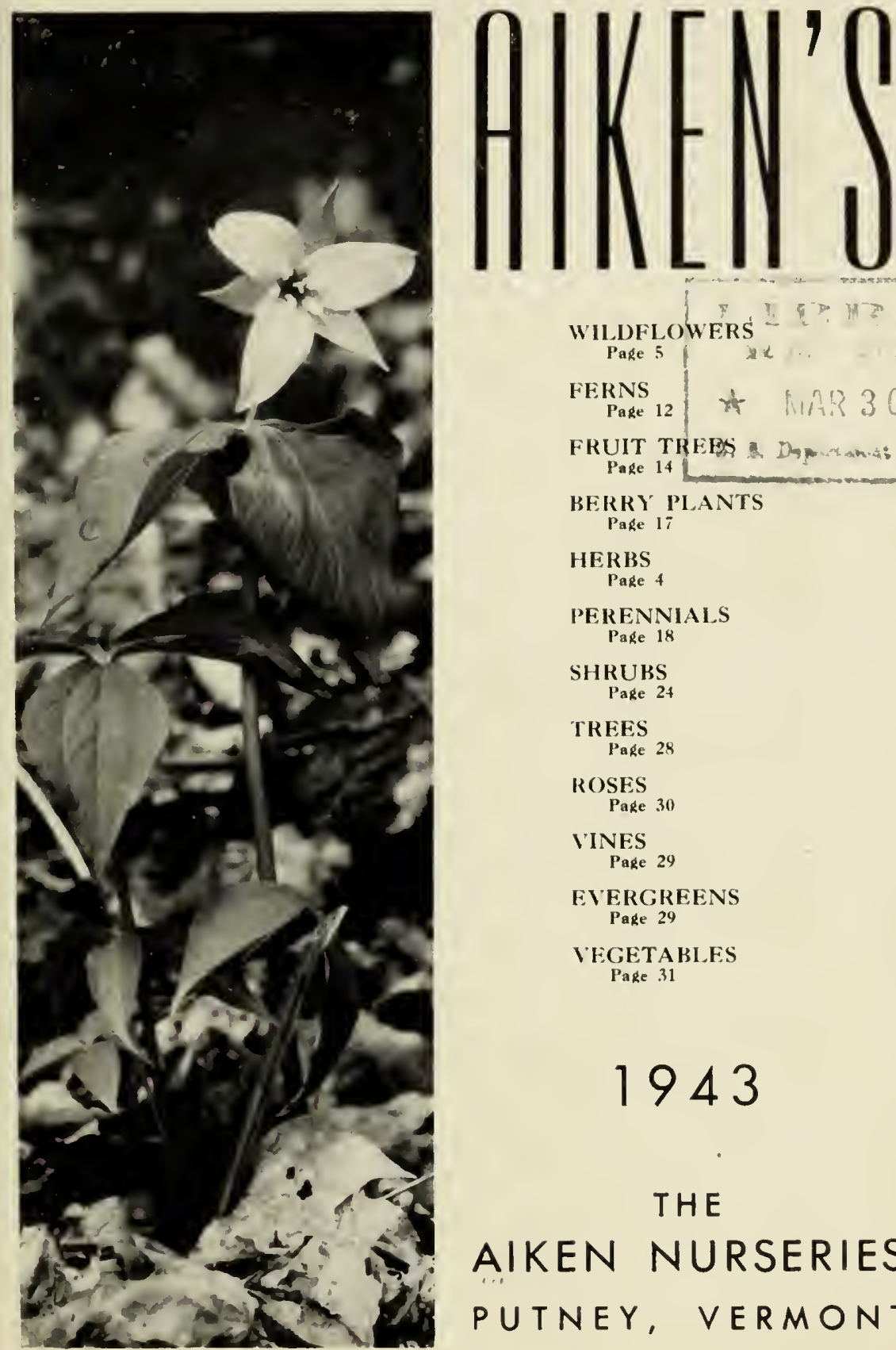

WILDFLOWERS $-M ?$, MR

Page 5

FERNS

Page 12

th fiा? 3,01943

FRUIT TREPS a Dhpwants of detivelt Page 14

BERRY PLAN'TS

Page I $\bar{T}$

HERBS

Page 4

PERENNIALS

Page 18

SHRUBS

Pare 24

TREES

Page 28

ROSES

Page 30

VINES

Pake 29

EVERGREENS

Page 29

VEGETABI.ES

Page 31

\section{3}

THE

AIKEN NURSERIES PUTNEY, VERMONT 


\section{These Two Pages Are Important To You!}

\section{Your 1943 Catalog}

This is your catalog. These nurseries exist only' to grow the plants you want in your gardens. Because plants grow slowly we hare to guess what you will be wanting in from two to ten years. If we fail to guess right. we appreciate being told. Since we work with plants all the time, we can often help you with advice as to varieties and suggestions regarding culture. IVe are always glad to receive and answer your letters, but please, in these days when labor, materials and tools are nearly non-existent, try to ask the hard questions and the involved ones before or after rush periods.

If you know of friends who might enjoy a copy of the catalog. will you send us their names and addresses? You'll be helping them, us and yourself, for the more we sell the lower we can set the prices.

Specialties this year, in addition to our well-known native Wildflowers and Ferns, are Fruit Trees, Berry Plants and Herbs. There is also a good buy in Roses listed at the back of the catalog.

A new feature of the catalog is the convenient price chart on page 3. which tells the cost of two or more at a glance.

With a few evident exceptions, plants are listed alphabetically by their Latin names under the various headings.

Remember our slogan:

"Grown in Vermont, It's Hardy"

\section{0\% DISCOUNT UNTIL MARCH 18}

In order to avoid delay and confusion at the neak of the Spring planting scason, we are offering you our usual incentive to send your orders early. On all orders received after this catalog is mailed and before March $18 \mathrm{~h}$, a discount of $10 \%$ will be given. Payment must be included with orders.

TRANSPORTATION: 'The customer pays all transportation charges from Putney. We pack the plants and deliver them to the local Post Office or lixpress Station without charge. They are sent by parcel post or railway express. whichever is (1) quicker and (2) more cconomical, unless you expressly indicate your preference. If parcel post shipment C. O. D). for postage only would not be convenient for you. please ask us to prepay shipment. IIe will bill you for the amount of the postage. 
PLANTING AND WATERING: Please unwrap the plants as soon as they arrive. Set them out at once or, for second best, heel them in. Fruit trees and dormant slirubs may be left in ordinary cellar storage for a few days if roots are kept moist in the facking naterial. Never wet the tons of strawberry plants; it rots the crowns. When the ground is dry during the first season, water thoroughly twice a week. "Sprinkling" does more harm than good.

GUARANTEE: All stock is guaranteed true to name and free from disease. Certificate of inspection accompanies each shirment. Since we have no control over transportation facilities. planting or care of stock after it leaves our hands. We make no guarantee as to growth. but-

CLAIMS: If any stock reaches you in unsatisfactory or danaged condition, flease notify us at once. We must insist that this be done within 5 days of receipt of goods. Should you receise a shimment damaged in transportation. BE SURE to secure the bad order receipt from the carrier's agent before accepting delivery. This will substantiate the clain for damages you make to the carrier. Dried out plants can often be saved by an orer-night soaking in a pail of water.

HOW TO SAVE MONEY: The following Price Chart shows how. If you are ordering more than one of the SAIIE VARIETY of plant to be sent to one address, you are entitled to a saring. If, for example, you are ordering 9 plants of Ajuga reptans, which is listed at $35 \mathrm{c}$ each. find that price in the left-hand vertical column and follow it across to the "9" column where you find $\$ 2.25$ to be the price of the plants.

For quantities of 13 through 25, the 25 rate applies. Example: Suppose 20 plants of Ajuga reptans to be ordered. Find the price of 25 plants as above. Divide this price by 25 and multiply by 20. $\$ 6.00 \div 25=\$ 0.24 ; \$ 0.24 \times 20=\$ 4.80$, which is the price to pas..)

Twenty-six or more plants of the same rariety take the 100 rate.

PRICE CHART

\begin{tabular}{|c|c|c|c|c|c|c|c|c|c|c|c|c|c|}
\hline \multicolumn{14}{|c|}{ Quantity of plants of same variety and size } \\
\hline 1 & 2 & 3 & 4 & 5 & 6 & 7 & 8 & 9 & 10 & 11 & 12 & 25 & 100 \\
\hline$\$ 0.20$ & .30 & .35 & .40 & 0.50 & .6 & 0 & 0.80 & $\$ 0.90$ & $\$ 1.00$ & $\$ 1.10$ & $\$ 1.20$ & $\$ 2.25$ & $\times 9.00$ \\
\hline & & & & & & & & 1.35 & & 1.65 & & & 13.00 \\
\hline .5 & .5 & .65 & .80 & 1.00 & 1.20 & & 1.60 & 1.80 & 2.00 & 2 & 0 & 4.75 & 19.00 \\
\hline .3 & .6 & 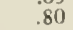 & 1.00 & 1 & 1.50 & & 2.00 & 2.25 & 2.50 & 2. & & 6.00 & 22.00 \\
\hline .4 &. & .95 & 1. & 1. & 1.80 & 2. & 2.4 & 2.7 & 3. & 3. & & & .00 \\
\hline 45 & .8 & 1.10 & 1. & 1. & 2.1 & 2. & 2.7 & 3.15 & 3. & 3.85 & & 8.25 & 31.00 \\
\hline .50 & .9 & & i. & 2. & 2.40 & 2.8 & 3.2 & 3.60 & 4.00 & 4.40 & & & 36.00 \\
\hline .60 & 1.1 & i. & & 2. & 3.00 & 3.50 & 4.0 & 4.50 & 5.00 & 5.50 & & 11.75 & \\
\hline .7 & $\because$ & 2. & 2. & 3. & 3. & 4. & 5. & & 6. & & & & \\
\hline.$s$ & .5 & 2.15 & 2.8 & 3.5 & 4.20 & 4.90 & 5.6 & 6.30 & 7.00 & 7.70 & 0 & 5 & 56.00 \\
\hline 00 & 1.70 & 2.45 & 3.2 & 4. & 4.80 & 5.60 & 6.4 & 7. & 8.00 & 8.80 & & 0 & 64.00 \\
\hline 10 & i. & & 3. & & 5.40 & 6. & 7.2 & & & 9.90 & & & \\
\hline & 2. & 3.50 & 4 & 5. & 6.90 & 8. & 9.2 & 10. & & & & & \\
\hline 1.50 & 2.9 & 4.25 & 5. & 7. & 8. & 9. & 11.20 & 12 & 0 & & & & 112.00 \\
\hline 1.7 & 3.4 & 5.00 & 6.6 & 8.25 & 9.90 & 11.55 & 13. & 14. & 0 & & & & 132.00 \\
\hline 2.0 & 36 & 5.30 & 7. & 8. & 10.50 & 12. & 14 & i & & 19 & 21 & & 140.00 \\
\hline 2.25 & 4.1 & 6.00 & 8.00 & 10. & 12.00 & 14.00 & 16. & 18 & 20 & 22 & & 45.00 & 160.00 \\
\hline 250 & 4.7 & 6.75 & 9.00 & 11. & 13.50 & 15. & & 20 & & & 27. & & \\
\hline 2.75 & 5.25 & 7.50 & 10.00 & 12.50 & 15.00 & 17.50 & 20. & 22 & 25 & & 30. & & \\
\hline 30 & 5.7 & 8.2 & & 13. & 16. & 19. & 22 & 24 & & & 33 & & \\
\hline & 6.75 & 9 & 13 & 16. & 19. & 22.75 & 26. & 29 & 32 & & & & \\
\hline 4.00 & 7.75 & 11.25 & 15.00 & 18.75 & 22.50 & 26.25 & 30.00 & 33.75 & 37.50 & +1.25 & 45.00 & …… & ............. \\
\hline 1 & 2 & 3 & 4 & 5 & 6 & 7 & 8 & 9 & 10 & 1 & 16 & 25 & 100 \\
\hline
\end{tabular}

See Price Chart on page 3 if you are ordering more than one plant of a variety. 


\section{HERBS}

Once a hobby-Now a necessity.

Easily grown-Put them in the vegetable garden.

Decorative_Plant them among your perennials.

Useful-Set them near the kitchen door.

\section{PERENNIAL HERBS}

\section{Price 30c each}

SWEET WOODRUFF, Asperula odarata. Graceful little plants with sweet scented foliage. Dried laves and flowers impart the odor of new-mown lay to clothes chests and keep away insects. Partial sls ade.

CHIVES, Allium schopuoprosum. Onion flavor Chopped for salads and to flavor cottare-cheese. Rosy-purple flowers.

WORMHOOD, Artemisia absinthium. Silky white leaves: yellowish flowers, Beneficial to poulery.

OLD WOMAN, Artemisia stelleriana. Ves? showy, silver-white foliage.

TARRAGON, Artemisio dracunculus. Pungent leaves used in scrambled eggs, greell peas and Tarragon vinegar. Small plants only are offered this year

SILVER QUEEN, Artemesia sp. A foliage plant. ANGELICA, Augelica sp. Aromatic. Once supposed to possess "angelic" healing properties.

CAMOMILE, Anthemis nobilis. For Camomile tea.

SWEET MARY, Chrysanthenum balsamita, tanacetaides. Fragrant, loug green leaves.

H)SSOP, Hyssapus afficinalis. Leaves and tops for Myssop tea. Aromatic. Often grown is a pot plant.

L. IVEDER, Lavendula z'era. "Nose licob." l'ragrant. Dried flowers used in sachets.

I.OVAGE, Levisticum afticinale. Aromatic fruit for candy-making.

PENNYROYAL, Mentha pulegium. I good ground cover witl framant foliage. Obnoxious to mosquitoes.

SPEARMINT, M. spicata. For mint jelly, iced lea and other drinks. Nlso used in candy and icing: IPPLEMIINT, M. rolundifolia.

P'EPI'ERMINT, $\boldsymbol{M}$, piperita. To $3 \mathrm{ft}$. with purple or white Howers. Leaves and stems for flavoring and distillation of Peppermint oil.

WOOLLY MINT, M. sp. Fuzzy foliage.

CURLY MINT, M. spicata crispata.

ORANGE MINT or BERGANOT MINT, H. cilrala.

HOREHOUNI), Harrubinn tulgarr. Jor makinh candies useful for coughe and colds.

LEMON BALM, Melissa afficinalis. Aromatic leaves used for seasoning liquers and in medicine.
CAUCASIAN CATNIP, Vepela mussini. grayish leaved plant with profuse violet-blue flower: 1 good edging plant for herb or rose beds.

RUE, Ruta gravealens. Atractive gray fuliage Young leaves used in sandwiches.

HORSE RADISH, Radicula ormoracia. Fleshy root is zrated for use as a relish with meal, baked beans and other foods.

SAGE, Salvia afficinolis. Seasmning and as a $4: \mathrm{h}$ stitute for tea.

LAVENIDEK COTTON, Sautoliwa chamoecyparissus. [seful for edgings and bordering walk= Gray folitige.

GREEN LAVENDER COTTON. Green foliage WINTER SAVORY. Satureia mantama. L'seful i। neat dressings.

BURNET, Sanguisorba canadensis. Flaming. WOOLLY BETONY, Stachys lanata. W(ull! leaves used medicinally' in ancient times.

TANSY, Tanecetum oulgare. lised against wom and in bitters. Ints hate it.

CURLY-LEA VEI) TANSY. Dark green ledre, ar daintily curled and feathered. Iromatic

COMION THYME, Thymus zulgaris. I.we are used fresh or dried for flavdring dressing, alu for sensoning. I iseful between flagstones.

LEMION THIME, $T$. ser $p y / l u m$ vnlgaris. Foliag smells and tastes of lemon.

SCARLET THYME, $T$. serpy/lum. I casperin plant for stome steps, terraces and dry bank. Purple-red flowers.

WHITE THIME, $T$. $\boldsymbol{s}$, albus. Tins white fluser sprinkled on bright grten leaves.

\section{POT HERBS}

(Not lardy, but often toteut imdosers in winter.

Price 30c each

SWIEET MARJORAM, Origaum marjorma Iromatic leaves used for seswning.

MARJORAMI, (), onises. Purple or white flower. larwer than those of Sweet Marjoram.

PARSLEI. Pelroselinum horlrnse. Fasily glum: standby for sea-oning and garmislies. There shomit be a pot in every hitchen window.

IROSEMARY, Rasmarinum officinalis. Fin Te membrance. Ilso teeped for at te.) to relieve liend aches.

See Price Chart on page 3 if you are ordering more than one plant of a variety. 


\section{ANNUAL HERBS}

Price $20 \mathrm{c}$ each

SWEET BASIL, Ocinum basilicum. Iromatic. l.entes used to season sours, stews, sances and meats.

DII.L. Anethum graveoleus. Seeds used to flotor inezar to make "dill pickles."

CHERVIL, Anshriscus cerefolium. l.cases em. ployed in salads and to garmish.

Bo)A(;E, Baraga afficinalis. Fragrant leaves are muxed with lettuce in salmk. boiled like spinats ir used in iced drinks.

CORIANDER, Cariander satizum, Seeds used in preserving and to flavor somsage. The seeds smell tuld taste of orange.

SWEET FENNEL, Foeniculum vulgare. Tiste wnewhat like celery" and used like it in salads.

IVISE, Pimpinella anisuu. Seeds for flavor.

SUMMER SAVORl, Satureia hartensis. For dresings with meat and in sausage.

CARAWAY, Carum curvi. Seeds nsed to flivor hread. pastry. hieese, sauces, etc.

Read some of the many good herb books at your mublic library. We especially like Ilelen Morgenthan Fux' "Gardening with Hlerbs."

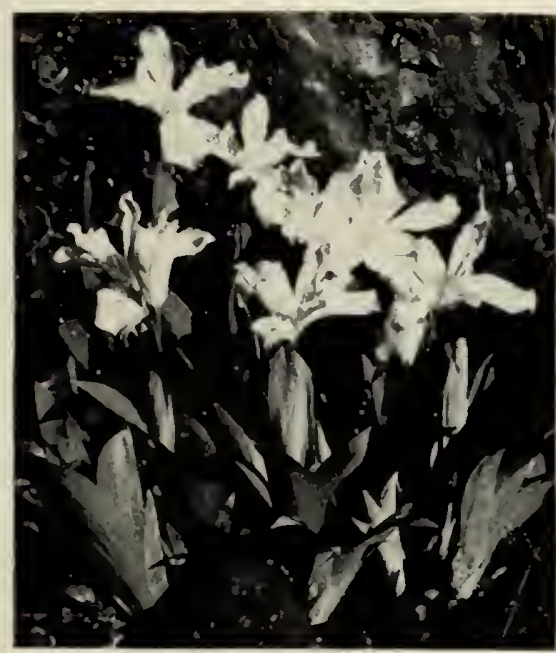

IRIS CRISTATA

\section{AMERICAN WILDFLOWERS}

CLAMBLKING; MONKSHOOD, Acanitum $U \mu$. cinatum. Slate blue. July. Partial shade in rich garden soil. $\mathbf{5 - 7}$ lt.

SWEET FIA A, Acarus Culamus. Brownisle yelluw. Rhizome very fratant-commonly used for making cindy.

WHITE BANEBERRY or DOLL'S EYES, Actaea Alba. Crem-w hite feithery flowers in May followed hy suow-white dusters of glossy berries eacli tipped with a dot of blark. Dense or light shade in rich leaf molk.

RED BANEBERRY, Ictara Rubra. Fluffy white flower heads in May. Intenve red clusters of berrie. in July and lugust. Slade and leaf mols.

WINIFLoWER, Anemane Oninquefolia. Tiny white fairy drinking cups in May. Partial sliade. Whod soil with leal mold. Four to seven inches. These completely disappear after flowering so be care ful not to disturb their bed.

RUE ANEMIONE, Anemunella Thalictraides. Iacy durk green folinge. White flowers on airy stens in May not unlike strawberry blossom. Partial shade. Rich woud soil. $4-7$ in.

AMERICAN COLUMBINE, Aquilegia Canadensis. Bell-shaped long-spurred flowers in May and lune. Bright red outside and clear yellow within. Filled with nectar beloved of the humming birds and bumblebees. Sunny or shady rock cliffs or wild garden. Any gond soil. I-2 lt.

SANIDORT, Areuaria Stricta. I rase Sindwut with it fountain of myriad white, starry flowers for smny cratgs and cliffs. May into July.

GREEN I)RAGON, Arisaema Dracontium. Inique. I little later flowering than Jack-in-thel'ulpit, If you have Jack you should have a Green Dragon to guasd him.

IACK-IN-THE-PULPIT, Arisaema Triphyllum. Remembered by all who have spent their childhond in lermont. Moist woodsy soil in partial shate. Brown green-striped hooded flowers in $\mathbf{M a y}$ followed by tight clusters of red berries in late Sunmer. $12-18$ in.

COMIMON GOATSBEARI), Aruncus sylvester. Creamy, white downy spikes spraying down over the lizhe green foliage. July. Quite dense shade. Ileavo wod soil. $\mathbf{3 - 4}$ It.

WILI GINGER, GINGER ROOT, Asarmin Canadense. lleart shaped fuzzy gray-green leaves. Tiny deep maroon three-petaled flowers resting on the ground in late Ipril and May. Partial shade. Rich wool soil. 3.4 it.

SWAMP MILKWEEI), Asclepias Iucarmata. Deep rosy red fower lieads on three- to five-foot stalks. Late June and July. Sun or only light shade. Mloist loamy soil or bogs.

BUT TER FL Y WEED, Asclepias Tuberasa. Flower heads of lemon yellow varying to dark flame. July and Lugust. Full sun. Grod garden soil. Wiell drained situation. From the time this flower starts to bloom it is a host to myriads of gaily marked b.itterflies.

Prices on Wildflowers except as noted, are $35 \mathrm{c}$ each.

See Price Chart on page 3 if you are ordering more than one plant of a variety. 
IIEATH. ASTER, Aster Ericoides. Sprays of misty white as beautiful as Gypsophila. September and October. Full sun. Dry soil, $2-3 \mathrm{ft}$.

NEW ENGLAND ASTER, Aster Novae-Augliae. Deep blue flowers on four-to six-foot stalks. Florets an inch across. September. Full sun. Rich garden soil. For backgrounds of the garden, open sunny glades or borders of the woodland or shrubbery.

PINK NEW ENGLAND ASTER, Aster NovaeAngliae Rosea. Like the above except that the flowers are rose color. It is not so tall a grower.

WILD CALlA, Calla Palustris. Waxy white flowers in June like the old fashioned indoor Calla Lily only smaller. Five to nine inches. Cardinal red fruit follows the blossoms. For the shady bog or border of your pool.

MARSH MARIGOLD, Caltha Palustris. 1 dash of gold for your sunny bog. Brilliant yellow wide open flowers in May and early June. Rich glossy green leaves. Easy as grass to grow and very hardy.

WILD HYACINTH, Camassia Esculenta. The Camassias are excellent for mass planting in moist or semi-shady locations. The bulbs were a favorite food of the Indians. The plants grow to about two feet in height and the flowers vary from cream to blue.

BLUE WILD HYACINTH, Camassia Leichrlini. This is a taller growing, rare variety, usually in deep blue. The Camassias blossom in May with us.

BLUEBELLS OF SCOTLAND, Campanula Ro. tundifolia. No flower has more grace than this one as it clings, dancing in the breeze on a dry cliff. The small blue bells are borne on delicate stems nine to twelve inches high. Blooms from June until frost, preferring fairly rich dry soil and full sun or very light sliade.

WILD SENNA, Cassia Marilandica. Clusters of clear yellow flowers with small black stamens borne on stalks often five feet high. Prefers full sun, but will grow in either dry or wet soil. July and August. The individual flowers are not unlike those of the Canary bird vine and are beautiful in a bouquet with white phlox.

BLUE COHOSH, Caulophyllnm Thalictroides. A native of the rich woods, making an attractive plant two feet high. The small, yellow flowers with purple sepals are attractive in early Spring and are followed in late Summer by clusters of intensely blue berries

TURTLEHEAD, Chelane Glabra. White spikes on two-foot stems similar to Physostegia except for larger individual flowers. Easily naturalized in rich soil around the garden pool. September.

SPOTTED PIPSISSEWA, Chimaphila Macnlafa. A splendid ground cover with notched green leaves mottled cream. Dainty bell-sliaped flowers on sixinch stems in June. Prefers a dry situation, acid soil, and thus the shade of fir or oak trees.

PIPSISSEWA, Climaphila Umbellata. Like the above except that the leaves are plain, snooth green - like Japanese lacquer.

CREEPING SNOWBERRY, Chiagenes Hispidula. I trailing vine demanding pure leaf mold and dense shade. White berries lasting throughout the Summer. The leaves are glossy green, small and round. Potted plants.
BLACK COHOSH, Cimicifuga Racemosa. Thrises in rich soil and rather dense shade. Grows to five feet with fluffy white spikes of flowers beginning in July.

SPRINGBEAUTY, Claytonia Jirginica. A most -delicate early Spring wildflower, white with pink markings. Easily grown in partial shade and leaf mold from the hard woods. After blossoming. this four- to six-inch plant disappears througl the Summer.

BLUEBEADS, Clintonia Borealis. Broad, shiny: green Ladyslipper-like leaves. The prinurose yellow flowers similar to those of the Shootingstar cummence the last of May. Three blue beads are found on the top of the flower stem in September. Acid soil. Quite dense shade.

SPECKLED CLINTONIA, Clinfonia Umbellu. lata, Slightly acid soil. Partial shade. This Clintonia has three leaves, while the former has only two. Loose clusters of very lovely white flowers in July. Black berries in late Summer.

GOLDTHREAD, Coptis Trifalia. A creeper preferring very moist acid soil and light shade. The name Goldthread aptly describes the root whicl, has medicinal qualities. The plants have a delicate tiny, white, sharp petaled blossom in Midsummer. A lover of sour leaf mold.

BUNCHBERRY, Carnus Canadensis. An outstanding ground cover. Ideal for use in repuiring hurricane devastation in soft woods.

PALE CORYDALIS, Corydalis Glanca. Findy cut blue-green foliage. Minute sprays of pink flowers with yellow centers, shaped like blecding heart. May and June. Twelve to eighteen inches. Full sun. Rich dry" soil. A biennial resowing itself.

SMIALL YELLOW LADYSLIPPER, Cypripe. dism Parvifar w". Small bright yellow flowers.

YELLOW LADYSLIPPER, Cypripedium Pubes. cens. The common yellow Ladyslipper blossoming il May. Most easily domesticated in either sun or shade. Clear yellow slippers with brown ribbons and very fragrant. I2.18 in. 40e each.

SHOWY LADYSLIPPER, Cypripedium Spectabile. Not so hard to grow after all. Il'c have seen it thriving under an old pear tree in ordinary garden soil. Lovely eggshell white flowers flushed with rose. $50 \mathrm{e}$ each.

CREEPING DALIBARDA, Dalibarda Repens. Good ground cover in acid soil and partial shade. White flowers shaped a little like Woodsorrel. June and July.

ROCK LARKSPUR, Delphinium Tricorne. Decp blue flowers about the color of Spark's Aconitc. Twelve to eighteen inches. Early June. Prefers a dry, sunny rock garden situation. Becomes dorınant in Midsummer.

SQUIRREL CORN, Dicentra Canadensis. The low growing Dicentras are all excellent subjects for the sliady wild garden. They prefer a rock pocket filled with leaf mold. Appealing feathery foliage. This one loas white drooping flowers sometimes flushed pink. April and May. 6-9 in.

DUTCHMAN'S-BREECHES, Direntra Cucullaria. Pale yellow drooping flowers tipped deeper yellow in the center. April and May. 6.9 in.

Prices on Wildflowers except as noted, are $35 \mathrm{c}$ each.

See Price Chart on page 3 if you are ordering more than one plant of a variety. 


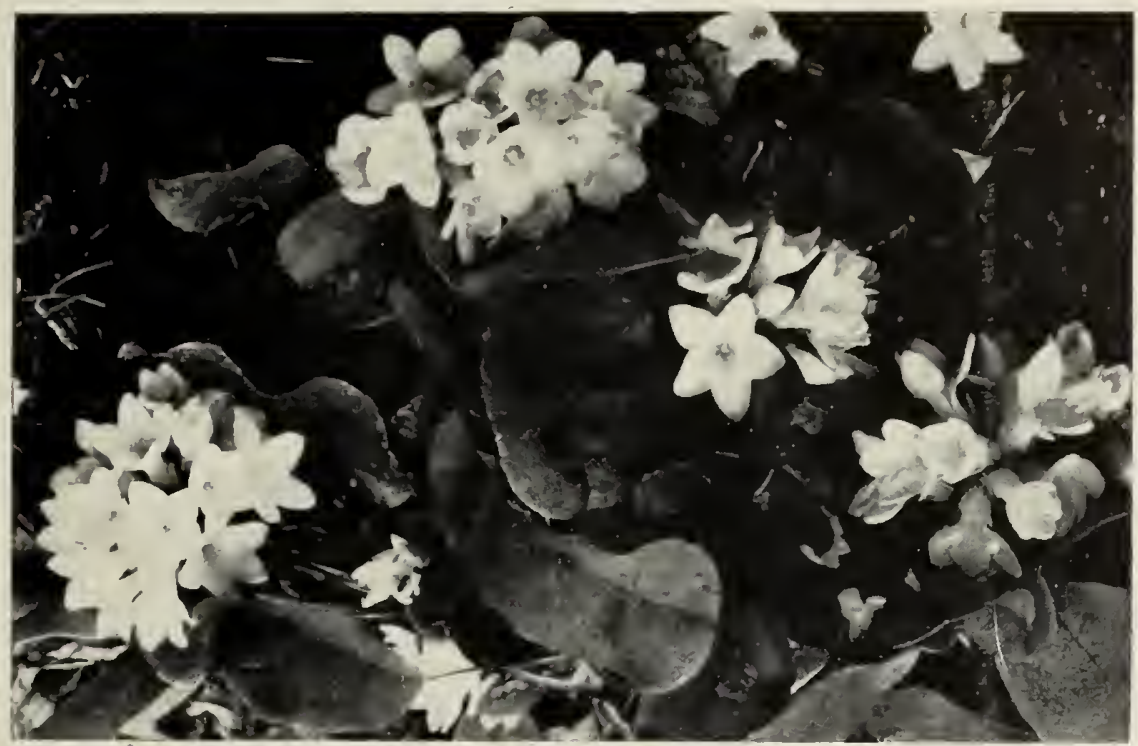

TRAILING ARBUTUS

TRAILING, ARBUTUS, Epigaea Repeas. Deliciously fragrant pink and white flowers. Sumewhat shy and elusive, but not too difficult to frow if vou have our compact litele plants each dug with a ball of earth and wrapped in burlap. 60e each.

FIREWEEI), Epilobinm Augnstifoliun. Giny spikes of pastel pink on two-font stems in June and fuly. Full sun. Dry soil. The separate florets are a bit like those of Cassia.

WHITE TROUTLILY, Erythrowium Albidum. A smow-white drooping flower.

COMIION TROUTLILY, Erythronium Ameri. cauma. Typical of the New. Fneland wools. Bright yellow flowerk, an inch across.

GLACIFRLIIY, Eryehroaiua Grandiformm. Forsythia yellow throughout. I'ain leaves.

HENDERSON TROUTLII,Y, Erythroninm Headersoni. lelvet wine color on the reflex part of the petals, large white center, and a deeper wine eye.

THOROUGHWORT, Enpasorinu Perlolialum. Flat dusky white flower heads on four-foot stems. Full sun. Swamp location. Thoroughwort tea made from the leaves of this plant was famous as an herb tonic when our grandmothers were children. late July through September.
JOE-PYEWEED, Eupatorium Purpurenm. Huge wine purple fower heads on four- to five-foot stems in late July through September. Full sun. Swamps and brooksides. Especially fond of this wildfower are the butterfies, particularly the Monarchs.

SNOW THOROUGHWORT, Eupatorium Urticaefolium. Perhaps the most beautiful of the fumily. Rich moist soil, somewhat drier than for the other two. Partial shade. August and September. Two feet. The flower clusters are as white as swan's down and contrast well with the dark green notched leaves.

GALAX, Galax Aphylla. I.ustrous leathery leaves. Ground cover. Valuable for use as foreground under broad-leaved evergreens. Acicl soil. Native in the South, but perfectly hardy here.

CHECKERBERRY - WINTERGREEN, Gawltheria Procumbens. The thick glossy leaves on a creeping plant with white bell-like blossoms of waxy texture, sometimes tinged pink. Icid soil. Fixcellent for growing in light shade under pine trees. Bright red berries in Jutumn.

BLIND GENTIAN, Gentiana Andrewsi. Groups of vivid cobalt blue in late July and August. Light shade. Damp, moist snil. 12.18 in.

NARROW-IEAVED GENTIAN, Gentiana Liaearis. Tubular fowers of lavender blue in clusters of five. Moist situation. Partial shade. July.

WILD GERANIUM, Gerawin on Maculatnu. Deep lavender flowers an inch across in late May and June. Loves the shade of bushes around rail fences. 12.18 in.

Prices on Wildflowers except as noted, are 35c each.

See Price Chart on page 3 if you are ordering more than one plant of a variety. 


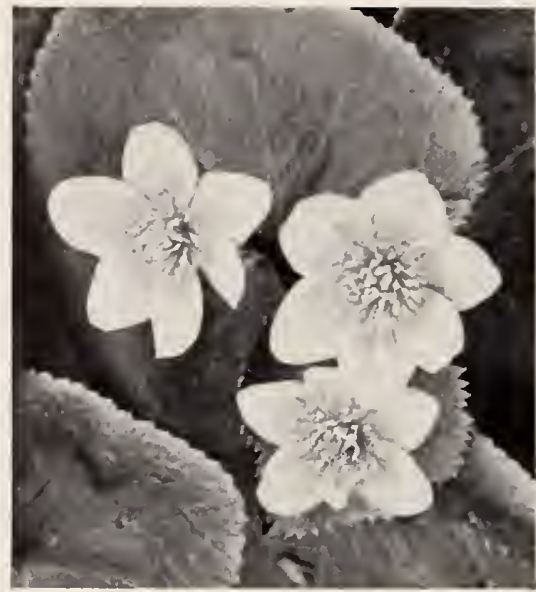

MARSH MARIGOLD

HERB ROBERT, Geranium Robertianum. Minute pink blossoms on nine- to twelve-inch stalks. Partial to crevices of rich soil in the rocks. Of altogether dainty appearance. June until frost. No better subject for the shady wild garden.

BOWMANSROOT, Gillenia Trifaliata. Snowwhite flowers similar to the Canada Violet only larger in two- to three-foot stems. Good garden soil. Lends itself wonderfully to naturalizing in sunny locations. June.

RATTLESNAKE.PLANTAIN. Gaadyera l'ubes. cens. In interesting plant with oval green leaves mottled white which grow close to the ground. Piney soil. Spikes of flowers like Ladies Tresses in July.

CREEPING RATTLESNAKE - PLANTAIN, Gaadyero Repens var. Ophioides. Leaves smoother than the former and paler green. Both the Rattlesnake-plantains are pretty for clish gardens.

YELLOW FRINGE-ORCHID, Habenario Ciliaris. In Auyust, the orange-yellow flowers rise on one- to two-foot flower stalks from the wet meadows and bogs. 60e each.

LARGE PURILE FRINGE-ORCHID, Habe. naria Fimbriata. This seems to be our most desirable Orchid, due to its delightful fragrance and lavendar pink color. A native of the bogs, growing to he two feet tall. $40 \mathrm{c}$ each.

SIIALL PURPLE FRINGE-ORCHID, Habenaria Psycades. Is somewhat smaller and earlier than the finhriata, and with a most elusive fragrance. toe each.

SHARPLOBE IHEPATICA, Hepatica Acutilaba. Associated with maple sugaring time here in Vermont. Delicate flowers sometines tinted blush, and pale blue on slender stems two to four incles high. Ibove lant year's reddish-brown three-hobed leaves these dininutive blossons quiver in the Aprit wind. Veutral Woodsy soil or leaf nold. Partial shade.
KOUNDLOBE HEPATICA, Hepatica Triluba Leaves not so sharp as the ahove. Flowers brichtel blue.

QUAKER LADHES, Haustoniu Cuerulea. Minute four-netaled. pastel blue blossoms on thread-fihe stems. Awakened to life by the singing of the robius in April. Nore or less continuous bloomer. Naturzlizes readily in short pasture grasa. Full sun. ID.e best in clay suil. 25e each.

GOLDENSEAL, Hydrastis Conadensis. IVide wrinkled, thick leathery green leaves five-parted. Belongs in the shady nook of every herb gardes for the yellow roots are used in medicine. Rich. moist soil. Flowers in June made up of whize stamens on stems about one foot ligh. Dark red berries in late Summer and Autumn.

THE VELLOW: STARGRASS, Hypoxis Hirsuta. Tiny, round gleaming yellow flowers in very duar iris-like foliage. Fult sun. Wet or dry location. Commencing in late May the flowers often continue into August.

ELECAMPANE, Inula Helenium. Sunflower-lihe blossoms, one to two inches across during August and September. Long, broad, plush-tike, gray-greel leaves. Two to four feet. Full sun. Ordinary snil. Dry or moist situation.

CRESTED IRIS, Iris Cristata. No early flowering plant is more desirable for the lighty shaded rock garden. Sky blue, flat blossoms cover the plant in May.

WHITE CRESTED IRIS, Iris Cristata Alba. Magnificent, smooth. white flowers tipped gold on the inner edges. Same culture as above. Four 10 sir inches. 50e eaeh.

CUBESEED IRIS, Iris Prismatica. Slender alid comely. Grow's one fom high in an ordinary garden situation. Taller under more moist conditions. Like sun. A beautiful blue in late Spring.

VERNAL IRIS, Iris Ierua. Charmingly modes? the orange crested sky blue flowers of the Iris lern. are most at home in the dry woods or in the shad: rockery. It grow's four inclies tall.

BLUEFLAG, Iris Jersicolor. For sunny swany or marsly spots. Rich light blue flowers. Two t. three feet high. Jume.

COLORADO SANDLHY, Leucocrinum . Jontanum. I tiny blue little plant whose fragrant waxs: white clusters are borne early in the Spring on sten a few inches tall.

IFEA )OW LILY, I.jlium Conadense. Tative Lily that prefers moist sandy location. Stalks thire to five feet tall vield un to fifteen dainty yellow w orange colored blossoms in July. Full sun, or only lixht shade. Plant six inches deep.

WOOD LILY, Lilium Philadelphicum. Brillan native Lity useful for naturalizing or in the gardes Fwo to three leet tall with upright red or orance flowers. July-August. Prefers acid scril. Plane foir inches sleep.

TURKSCAP I.HY, Lilium Superbum. Dativ lily of easiest culture four to six feet tall with matis flowers of rich orange with recurved petals. II: sunumer. Plant six inclies deep.

Prices on Wildflowers except as noted, are $35 \mathrm{c}$ each.

See Price Chart on page 3 if you are ordering more than one plant of a variety. 
TWIN-FLOWEK, Linnaea Americana. Potgrown. "iw dainty pink bells on slender stems abont three inclees ligh. A charming creeper. J'ractically an alI vimmer bloumer. Prefers dense sliade in the acid suil of pines and hemlocks.

L.LY TWAYBLADE, Liparis Lilifolia. A yellow Alswering orchid. Moist leaf nold. Partial shade. l..te MIny and Jinne.

PUCCOON, Lithospermum Canescens. Bright yellow Ruwer gromp shaped like miniature Wiegela filowoms. May and June. liull sun. Any good siil.

C.IRUINAL-FLOWER, Lobelia Cardinulis. 'Two tort spikes of intensely scarlet blussoms in Angust. Fis nituralizing along streans of pools.

I. ARGE BLUE LOBELIA, Lobelia Syphilita Twi to three feet. Like the above except the flowers are larger and are heavenly blue. If you inde one Lobelia you should surely lave the other. IONEYWORT, Lysimachin Nummularia, An indispensable ground cover for either sun or shade. 1. beantiful hanging down over a gray wall. Tiny. (up-shaped yellow flower. For use on banks of under trees when grass will not grow.

SWAMP CANDLE, Lysimachia Terrestris. The name Swamp Candle exactly describes this plant. The llswers are closer together and much nearer the talk than are those of the Whorled loosestrife. Vimme ereenish brown petals form a second star inside the larper yellow sne. July and August. Twe to two and one-balf incles. Fixcellent for sunny loug and marshes.

PURPLE, LOOSES'RRIFE, Lythrum Salicarium Raseum. Perhaps our most conspicuous carly July Alswer. Compact dark pitik racemes. Full sun. Slishtly moist common scil. Three to four feet.

CANADIAN MAYFLOWER or WII.J LILY. OF.THE.VALLEY, Maian themum Canadensis. $A$ wee, fuffy, white flower cluster with a shiny, ovate leaf at its back. Lowes to grow in rich wood soil al the fort of great trees. P'artial sliade. Late May. Three to four inclies.

VIRGINIA BLUEBELL, Mertensia Jirginica. Bells of rose pink or sky blue. light shade. One (1) (wo) feet. Good garden soil.

MONKEY-FLOWER, Mimulas Ringens. Snapiragun flower of a particularly lovely orchisl hue. Most content in the sunny bog. July. 12-18 in.

PARTRIDGEBERRY, Mitchella Repens. A be:IUtiful wax-like, round-leif trailing vine with tiny, fragrant four-petaled white blossoms often flushed pink. June flowering. The cheerful red berries beginning in late Summer are held through the Winter into the following Spring.

MIITREWORT, Mitella Diphy/la. Pencil thin lower spikes. May, One foot. Rich shaley soil. Partial shade.

WHLDERGAMOT, Manarda Fistulasa. Outurling flower petals of lavender. July. Good garden soil. Two to three feet. Full sun or light hade.

ONE-FLOWERED PYROLA, Maneses Uniflora. (1)e delicate waxy white drouping flower on a stem wally six inches high. One of the sweetest wildhower udors. Round, pale green leaves nearly flat 1. hi the ground. June. Piney soil, Light shade.
TRUE FORGET-IIL-NOT, Myosotis Scarpi. aides. No better flower for naturitling alongsiale your tiny brook or around your pool. Minch senti ment is always attached to this dainty, tender blue cluster of fowers, Full sun or light shade. Rich. dark soil. June until frost.

WHITE: WATERIILY, Nymphaea Odorata. One of the purest, most fraprant of flowers. Wlite petal and conspicisous golden stamens. Blosson sometimes siv inclies across. Jume and July. Full sm. Happy in calm poeds.

WIITE FVENING I'RIMIROSE, ( ) nothera spe. ciosa. Frazile white flswers two inches broad on delicate stems sontetimes one foot high. Delicate foliage. June and July, Full sun. Rich, well drinined soil.

SHOWy ORCHIS, Orchis Spectabilis. One of the loveliest, most modest of wildfowers. A white lower petal ususlly overhung with three orchid purple ones. Several blossoms on each stem. IIard wood leaf mold. l'artial shacle. $40 \mathrm{c}$ each.

TRUE WOOHSORREL, Oxalis Acetosella. Delicate white live-petaled flowers with a multitude of pink lines. Shamrock leaves. Flower stems two to furr inches ligh. Quite deuse shade. leaf nold.

GRASS OF PARNASSUS, I'arnassia Caraliniana. I solitary white fower shaped a liztle like that of it butercup on a slender stem usmally one foot tall. ()vate pale green leaves. Liglit shade. Moist bugey soil. July and August.

EASTERN PENSTEMION, P'énsteman llirsutus. Spikes of white flowers with lilac shadings.

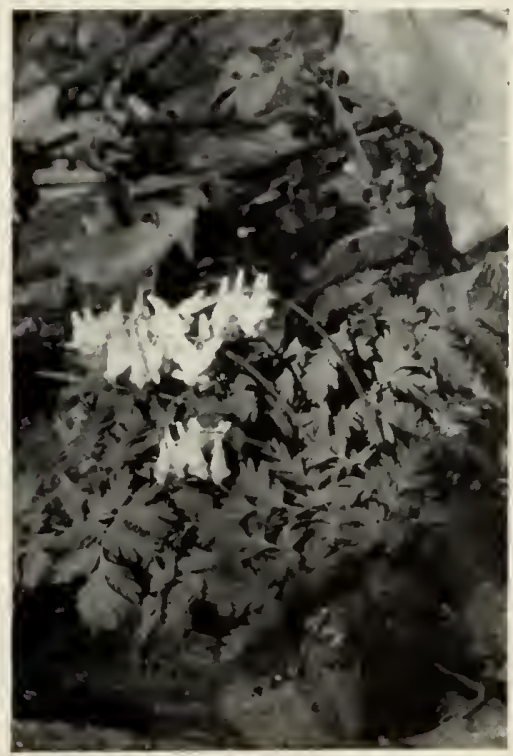

DICENTRA CUCULAARIA

Prices on Wildflowers except as noted, are 35c each.

See Price Chart on page 3 if you are ordering more than one plant of a variety. 


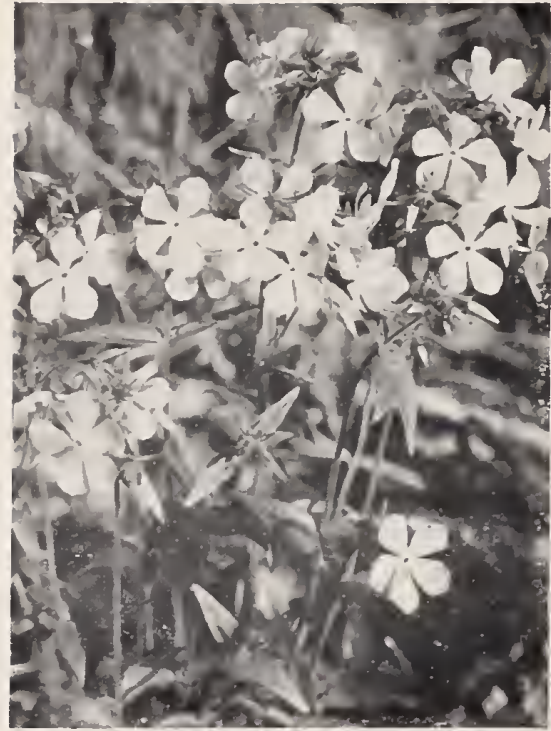

PHLOX IIVARICATA

AMOENA PHLOX, Phox Amoena. Rose pink clusters of flowers on six-inch stems. Florets an inch across. A living color in late April and May. Dry soil. Full sun.

CLEFT PHLOX, Phlox Bifida. The first of the Spring phlox to bloom. A shimmering assembly of pastel blue flowers. The florets are threc-quarters of an inch across and much frilled. Full sun. Dry soil.

BLUE PHLOX, Phlox Divaricata. Varying shades of soft blue or lavender flowers an inch across on nine- to twelve-inch stems. Individual blossoms are blunt five-pointed stars. Light shade. Rich woodsy soil. May. One of the very best wildflowers for naturalizing.

SMOOTH PHLOX, Phlox Glaberrima. Pale lavender pink clusters of flowers on stems ten to twelve inches tall. Full sun. Dry soil. A stead. fast bloomer beginning tate in June and continuing sometimes into September.

MOUNTAIN PHLOX, Phlox Ovata. The best of its color. Deep rose. A profusion of blooms in late May and early Jume. 8-12 in. Full sun. Dry soil.

DOWNY PHLOX, Phlox Pilosa. Airy foliage. Dainty flowers. Art shades of pink and blue with deeply: cut petals. Once in a while a pure white form is found. $8.10 \mathrm{in}$.

CREEPING PHLOX, Phox Reprans. This one is like Phlox Imoina except that it prefers acid soil and partial shade and blossoms about two weeks Jater. Rose pink.

Prices on Wildflowers except as noted, are 35c each.
FALSE-1)RAGONHEAI), Physostegia Speciosa. Two-foot spikes of sil apdragon-like fowers in J॥ly. Dry or moist situation. Full stln. Rich lilac rosc. MAYAPPLE, Podophyllnm Pellatum. Ivory white flowers one and one-half inclies across in Mav. Glaucous umbrella-like leaves. Yellow fruit in Autumn. Very light shade. Rich loam.

A.MERICAN JACOB'S LADDER, Polemoninm I an Bruntiae. Tall-growing and large-flowering. The color is rich blue. Mloist, rich soil. Partial shade. July.

SOLOMONSEAL, Polygonatmm Biflorym. Small green bells on gracefully overhanging leaf fronds sometimes eighteen inches long. Soil from the hard. woods. Dense shade. May and Jume. Blue berries in Autumn.

GREAT SOLOMONSEAL, Polygonarmm Commntatmm. 3-4 ft. Giant yellow bells in May and June. Light shade. Plant in rick soil.

BLOODROOT, Sangninaria Casadensis. Plant these snow-white starry flowers in great masses under your Flowering Crabs and Hawtlorms and alorg your shady paths, where they can bloom with the Primroses and Violets in earliest Spring.

BIRDSEYE PRIMROSE, Primula Farinosa. Onc of the daintiest of all primroses. Pale lavender flower heads. Dull silver leaves. Sative to tlic Northwest and to Europe. Wood soil. Light shade.

SHINLEAF, Pyrola Elliplica. Fragrant, waxywhite, bellshaped flowers in June and July. Light, neutral soil. Shade.

TRUMPET PITCHERPI,ANT, Sarracenia F/ava. Tall. yellow trumpets reaching a height of two leet. PITCHER-PLANT, Sarracenia Purpurea. I ft. June. Reddish green. A very curious plant found in swamps. It thrives on the insects which it catches in its pitcher-shaped leaves.

SWA.MP SAXIFRAGE, Saxifraga Penusylvanicum. "Imagine Mignonette blostons growing up three-foot hollow stems in the swamps in late May and you have a picture of the Swamp Saxifrape, from "Pioneering with Wildflowers" by George D. Aiken.

MOUNTAIN SAXIFRAGE, Saxifraga Jirgini. ensis. Small clusters of white flowers on three. to six-inch stems. They like best some cleft in the high rocks. Rich, dry soil. Full sun or light shade.

MOUNTAIN STONE CROP, Sednm Ternasm. The most adaptable Sedum for the wild garden. Misty white flower lieads in June. Smooth, deep green leaves. Prefers rich wood soil. Equally at home in either full sun or very light shade. 3-6 in.

OCONEE-13ELLS, Shorvia Galacifolia. A prince among the wildlings. Larke reddish green glossy leaves whicl, last the year ronnd. White mallow-like blossoms on stems six inclies high. Light shade. Acid soil. May.

BLUE-EYES-GRASS. Sisyrinchinm Augusifo. linm. Circular blue Howers wre-half juch across on minute iris-like foliage six inches high. Fairly mois? soil. Sunny situation. May and June.

THREE-LEAV'EI) FALSE SOIOMONSEAL. Smilacina Trifolia. $5-8$ in. Airy white flomel heads in June. Shade.

See Price Chart on page 3 if you are ordering more than one plant of a variety. 
FRAGRANT GOLDENROD, Solidago Odora. Fragrant yellow flowers. Open fields or borders.

LADIES TRESSES, Spiranthes Ceruua. Fragrant waxy, white orchid flowers on a six- to eight-inch stem. One of the daintiest of wild plants. Rich, moist soil in the sunny bog. August and September.

TWISTED STALK, Streptopus Amplexifolium. Very much like Solomonseal having white bells. May. Red berries in Autmm. Soil from the hardwoods. Partial shade.

ROSY TWISTED STALKS, Streptopus Roseus. Like the above except that the dainty bells are rose colored. Same cultural direction.

EARIY MEADOWRUE, Thalicerum Dioicum. $3 \mathrm{ft}$. Rich woods. Misty purplish flowers in May. Attractive, finely cut foliage.

TALL MEADOWRUE, Thalictrum Polyganum. 4-6 ft. A late Summer native at home near brooks and pools. Feathery flowers of pure white. Fine cut flowers. Thrives in the garden border.

FOAMFLOWER, Tiarella Cordifolia. Fluffy white flowers on stems sometimes eight inches high. May. Hardwood soil. Fspecially suited to the shady rock garden. Wonderful ground cover.

NODDING TRILLIUM, Trillium Ceruum. A nodding Trillium not too common, with blossoms of white. From the moist woods of the Central West, blooming in May.

WAKEROBIN, Trillium Erectum. Our own native Trillium of deep red, at home in the rich woods, blossoming in May and about a foot tall.

SNOW TRILLIUM, Trillium Grondiflorum. Great snow-white flowers often three to four inches across. A beautiful plant for a semi-shady spot in the garden or for naturalizing under tree.

DWARF WHITE TRILLIUM, Trillium Nivale. This six-inch variety comes from the Central West and is almost the earliest wildflower to blossom. It blooms with the Hepaticas and early yellow Violets and should be a wonderfully good rock garden plant.

PRAIRIE TRILLIUM, Trillium Recurvatum. Rich deep brownisb red flowers of peculiar formation, with recurved petals.

CALIFORNIA TRILLIUM, Trillium Sessile Califoruicum. A western stemless Trillium a foot tall with very large leaves and long petals. The flowers are ivory white and fragrant.

ROSE TRILLIUM, Trillium Stylosum. This rose pink Trillium comes from the southern mountains. The last of the Trilliunss to bloom.

PAINTED TRILLIUM, Trilliam Undulatum. Blooms in late May, the flowers being white with a red center and red veining in the petals. One of the most beautiful of the Trilliums. Should be planted in an acid soil in partial shade.

TROLLIUS LAXA. Soft luminous yellow cups. A most lovely and delicate shade. Extremely rare globeflower native to the East.

MERRY BELLS, Uvuloria Perfoliala. Cream white bells after the drooping stalks in early May. Favorite companion of the Snow Trillium.
CULVERS-ROOT, leronico Virginico. Tall ivory white flower spikes in August. Open sun.

SWEET WHITE VIOLET, Holo Blanda. Tiny white fragrant Violet for boggy places.

CANADA VIOLET, Iiola Conadensis. Grows to a foot tall with lavender and white howers for shady corner or woodland planting.

BLUE MARSI VIOLET, Violo Cucullata. Long stemmed deep blue flowers.

BIRUSFOOT VIOLET, V'iolo Pedata. A rich purple with fincly cut foliage. Grows to ten inches iis partial shade.

TWO COLOR BIRDSFOOT VIOLE'I, Violo Pedata Bicolor. Perhaps the showiest Violet, the upper petals being royal purple and lower ores rich
blue.

LILAC BIRDSFOOT VIOLET, Iola Pedata Lineariloba. The eastern form of Birdsfoot Violet, with very large blue flowers. Plants only grow four to six inches.

DOWNY YELLOW VIOLET, Viola Pubescens. Easily naturalized in any shady rather dry spot with Hepaticas and Bloodroot.

BARREN STRAWBERRY, Woldsseinia Fragarioides. A splendid ground cover. Rich glossy foliage and yellow strawberry-like blossoms.

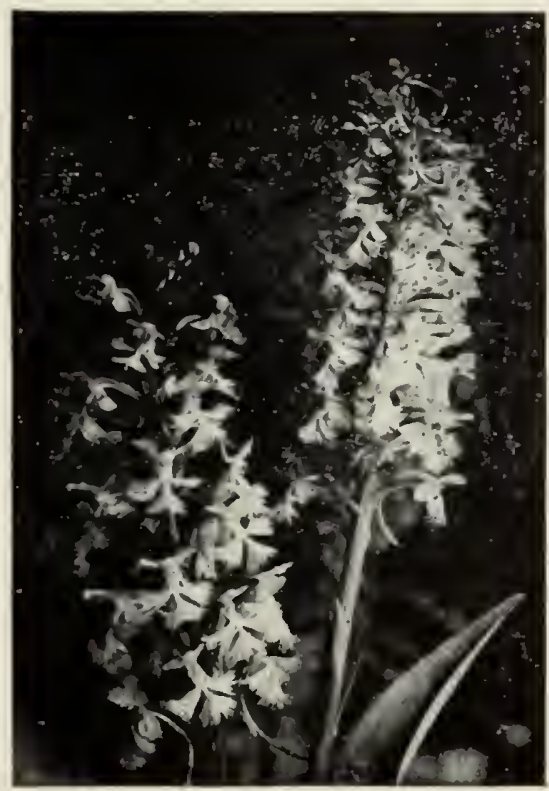

PURPLE FRINGE ORCHID

Prices on Wildflowers except as noted, are $35 \mathrm{c}$ each.

See Price Chart on page 3 if you are ordering more than one plant of a variety. 


\section{The Hardy Ferns}

One of the most useful of all groups of plants is the Hardy Ferns. Their value is bein: recognized more each year. There are many places which may he enhanced by their graic and beauty. The rockery, the woodland pathway. the brookside or border of the pond. or the north side of a building where little else will grow. All these places may be matic more attractive by the beauty of Ilardy Ferns.

Sec page 3 for reduced prices of quantities of the same variets.

MAIDENHAIR FERN, Adiantum Pedatum. The slender wiry black stems, crowned with indescribably heautiful spreading fronds, mingle with the Bloodroot. the Baneberries and Jack-in-the-Pulpit of the rich hardwoods. Two feet tall. $30 \mathrm{e}$ each.

EBONY SPLEENWORT, Aspleniuin Platyueuran. Ebony stems, slender and graceful, grows six to iwelve inches tall among the moist shaded rocks or glades in the woodland. $40 \mathrm{c}$ each.

MAIDENHAIR SPLEENWORT, Asplenium Trichamaues. Daintiest of all with clumps of slender fronds four to six inches tall growing in clefts of the rocks. Minst lave some shade. 40e each.

LAD) FERN, Athyrium Felixfoemina. An easily grown species two to three feet tall and at home in partial or full shade. A good fern for the anateur. $30 \mathrm{e}$ each.

SILVERY SPLEENWORT, Athyriut Thelyptroides. A fern similar to the Lady Fern, but with ilvery fruit dots. For moist shade. 40e each.

NARROWLEAF SPLEENWORT, Athyriut Pycnacarpan. Large vigorous fronds to three feet with rich green, ripply pinnae of most unusual appearance. For rich woodlands. $40 \mathrm{c}$ each.

BROADLEAF GRAPEFERN, Botrychium Matrirariae. A timy species ouly six inches tall from upen woods or gravelly pastures. One small frond growing from the side of the fruit stalk. Rare. 60 c each.

TERNATE GRAPEFERN, Batrychium Obliquum. To one foo with a rich leathery frond which lives through the Winter and becomes dormant in early Summer. Open gravelly soil. Mfost unusual. 40e each.

RATTLESNAKE FERN, Batrychium Virginianuin. From the dry open woods. One to two feet. A single spreading frond laalf the height of the fruil stalks. 30e each.

BERRY BLADDERFERN, Cystapteris Bulbitera. Supinely graceful slender frond to three feet. A semiprostrate species delighting in the companionship of small tumbling brooks of the woodland. where they are moistened by the spray. 30e each.

BRITTLE FERN, Cystopteris Fragilis. Slighty less than a foot tall and often mistaken for Woodsia. Becomes dormant in Auguse, but sends up new shoots during early Fall. 30e each.

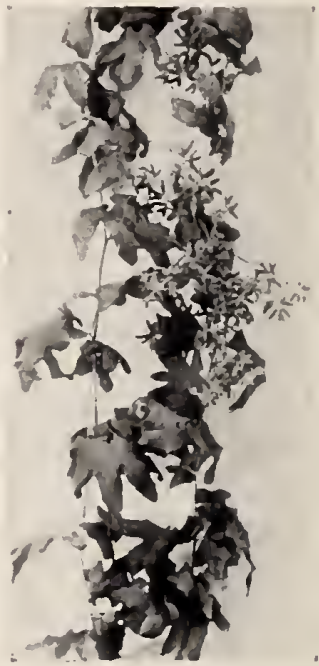

\section{CLIMIBING IERN}

HA ISCENTED FERN, Deunsfedica Puncrilo. bula. For sun or open sliade. Graceful twelve inch fronds which form dense mats as the specic spreads from the roots, Fragrant when cruslice Small clumps. 30e each. Sods about ten inclies square. $80 \mathrm{c}$ each.

CLINTON WOODI:EIRN, Dryapteris Clima. niana. A splendid moist whods specics with broa three-font fronds. Oue of the best. 40c each.

CRESTEI) WOODFERN, Dryapleris Crisiala. I small counterpart of Clinton Woodfern usuall on liumunocks in semi-shaded bogs. $T_{n}$ eichtee: inclies, $30 \mathrm{c}$ each.

See Price Chart on page 3 if you are ordering more than one plant of a variety. 
GOLIDE FERN, Dryopteris Goldionu. The larzest of the wond-ferns, attainink four feet and heing neirly evergreen. For rich moris woods. soc each.

WINGEI) WOODFERN, Dryopteris Hexogoneptera. Grows to eigliteen inches with fronds nearly as broad as tall. Fisily cultivated and increased rapidly, but rare in the wilds. Dry wonds. 40e tach.

FANCY FERN, Dryopteris Intermedia. A ne:arly esergeen fern with lovely fronds welve to eighteen inches tong. "The fern usest by florists in a weat extent. 30e waeh.

OAKFERN, Dryopteris Linneana. I tiny little four - to six-inch fellow with triangular fronds. comtimally sending up new fronds all Summer and preading from the roots. Moist woodland. 30e each.

I.EATIIER or EVERGREEN WOODFERN, l)ryopteris Marginalis. I true evergteen frond, thick and dark green and twelve to eizhteen inches lons. Onc of the best wodferns. 30e eaeh.

NEW YORK FERN, Dryopteris Noveboracencis. $I$ twelve- to eighteen-inch fern of the marshy woods. 30e each.

VARROW BEECHFERN, Dryopteris Phegopseris. In eight-inch heart-shaped frond of the drier wonkts. Grows atso with Oakfern in moister soil. 30 each.

IARSHFERN, Dryopteris Thelypteris. I small wight- in twelve-inch slender species of the marshes, $-\mathrm{m}$ or wiale. 30e each.

CLIIIBING FERN, Lygodiam Palmatum. I rate lumbinz species which in rich acid snil. Well supplied with hismus grows three to fous feet. Roughly maple-shaped leaves. $50 \mathrm{c}$ each.

SINSITIVE FERN, Onoclea Sensibilis. While this species grows only a few inches tall in open mesdlows, yet it attains a size of two to three feet in the bogs and assumes o rather tropical appearince. 25e each.

ADDERTONGUE FERN, Ophioglossum Vulgotum. I rare and curints fern with a single lancenlate leaf. Grows in either bogs or dry soil. Rare rather than beatuiful. 40e each.

CINNAIION FERN, Osmunda Cinuausoméa. In open or shaded bogs this attains four feet. Ntso Ĺrows in dry soil. Our most cosmupolitan species. 30 each.

INTERRUPTED FFRN, Osmanda Claytonia. Probsbly our lasgest species, in rich wonds or bogs making nearly six feet. 35 c each.

ROYAL, FERN, Osmunda Regalis. Wide spread iur wraceful fronds. it grows to three feet in the hacked buss and to a smatler size in the open fields. 35 e each.

COMIION POINPODY, Polypodium I'ulgure. six to eight inches tall, it grows in mats on ruchs, and ledges. For shacke. Fvergreen. 25e cael.
BRAUN HOLLIIERN, Polystichum Brauni. A native of the step, rich, rocky woods shere it prows two feet till. Iixtremely glossy deep green fronds and with chatly stems. 50e each.

BRACKEN, Pseridium Aquilinum, I spreading partect frond atop a two- to three-fout stalk. The Bracken yrous in full sun in rather dry pastures. 25e eaeh.

OSTRICH FERN, Peteretis Nodulosa, I giant fern that grows atong the banks of stieums and ponds. (of a graceful. plunzy grouth in six feet. Sun or shate. 30 c each.

RUSTY WOONSIA, "loodsia Ilvensis. It home in rock crevices in full sun. Pretty woolly fronds four to eight inches tall. Often becomes dormant in lugust, refoliating in September. 30c each.

COMIION WOODSIA, Noodsia Obtusa. A dainty species a few inches tall for the shaded rocks. 30 c each.

CHAINFERN. Hooduardia Areolata. I one- to rwo-font fern for swamps. So-called Chainfern berause the spores resemble chain links. 30e each.

VIRGINIA CIIAINFERN, Hoodwardia Virginica. Inother swamp species prowine to thirty inches. Spreads frum the roots. 30e each.

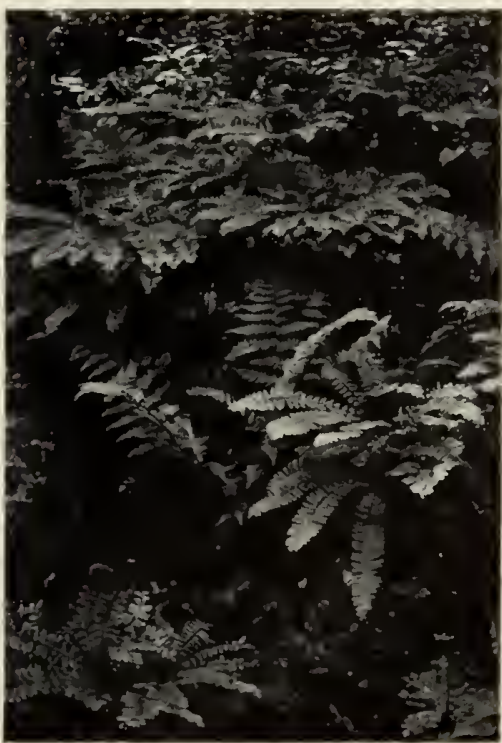

MAIISENHAIR FERN

See Price Chart on page 3 if you are ordering more than one plant of a variety. 


\section{FRUIT TREES AND BERRY PLANTS FOR VICTORY GARDENS}

We have a job shead of us feeding a large part of the world. Food grown at home saves labor, handling and transportation. It looks better, tastes better and is better than market produce.

For beginners as well as experienced home orchardists and berry-culturists we recomnend and offer at unusually interesting and instructive book, "Pionecring with Fruits and Berries," by George D. Aiken. $\$ 2.00$ per copy postpaid. (No reduction for quantitics.)

The varieties offered here are hardy, healthy, productive tasty varieties which have done well on our own or neighboring farms.

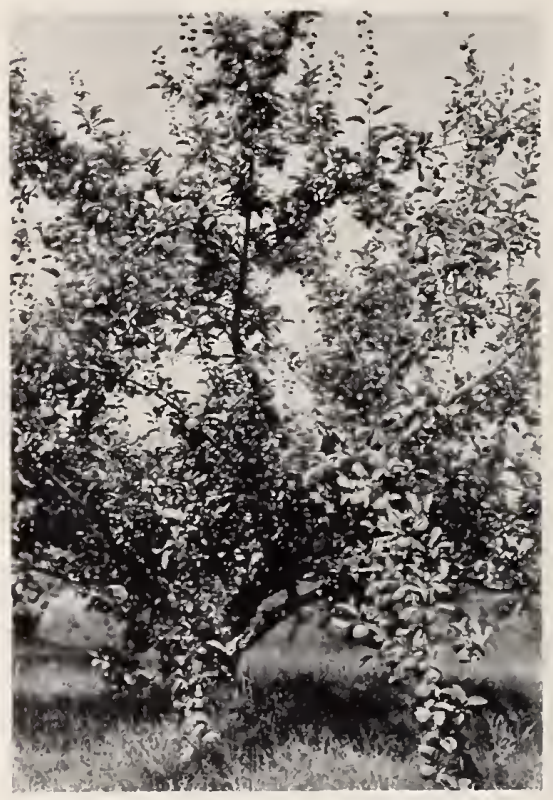

\section{APPLES}

Strong two-year trees, $1 \mathrm{I} / 16 \mathrm{in}$. ealiper, $5-7 \mathrm{ft}$. tall. Price $\$ 1.00$ each.

\section{SUMIMER VARIETIES}

RED ASTRACHAN. Red fruit ripens in August. $A$ hardy and vigorous varicty.

YELLOW TRANSPARENT, Golden fruit in late July. The earliest. Makes a small tree.

\section{FALL VARIETIES}

MeINTOSH. Red fruit ripens in late September and keeps well. Be sure to plant another variety. such as Red Astrachan. Cortland or Delicious. nearby to pollinate it. The "MIac" is the most popular variety in the Northeast.

EARLY IICINTOSH. Fruit similar to McIntorh but ripening in late August.

CORTLAND. A very hardy AIcIntosh hybrid. Ripens just after its parent. An outstanding variety which holds its large, red fruit on the tree,

RE! GRAVENSTEIN. A better, redder fruit than the popular Gravenstein of which it is a sport. Not so hardy as most we list in the extreme North. Ripens in September.

MILTON. This handsome new McIntosh variety ripens between Red Gravenstein and Melntosh. A hardy tree bearing pinkish-red, crisp fruit.

WEALTHY. Brilliant red, striped fruit in September. I hardy, vigorous, deservedly popular tree.

FA.IEUSE. Old-rime Snow apple. Limited stock.

\section{WINTER VARIETIES}

RHODE ISLAND GREENING. A fine large apple for Winter cooking and eating. Came 10 fermont from Rhode Island in the early 1800's and has retiined its popularity ever since.

BALDWIN. The well-known, bright red fruit is a favorite everywhere.

DELICIOUS, High quality, red dessert apple. Almost sweet in taste.

NORTHERN SPY. The red or striped fruit is cherished throughout New England. It may not be the best, but we think it is. Fruit keeps well.

FOR PEOPLE IN A HURRY, we have available a limited stock of older trees, near to bearing size, but not too large to be shipped safely and economically bare-root. Due to differences in type of tol' growth, sizes are given in caliper of trunk six inches from the ground. Many commercial or-

See Price Chart on page 3 if you are ordering more than one plant of a variety. 


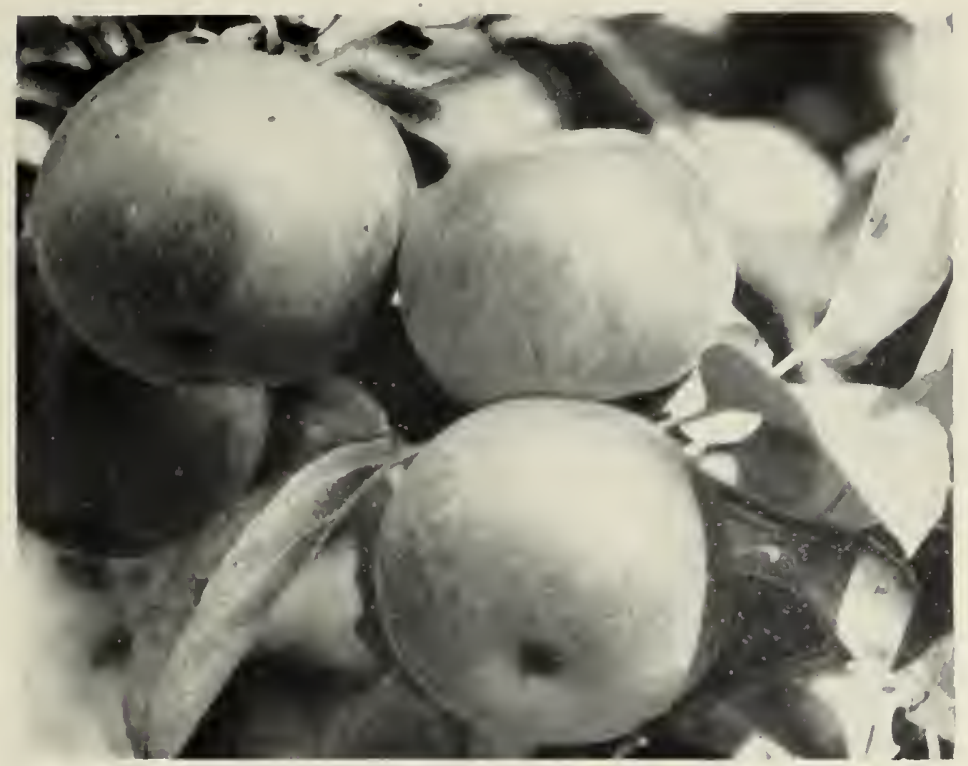

MCINTOSH APPLES

chardists buy only these larger trees in order to save time.

Prices: ${ }^{34}$ in., $\$ 1.50$ each; 1 in., $\$ 2.00$ each; $11 \%$ in., $\$ 2.25$ each; 2 in., $\$ 2.50$ each.

BAIDWIN. 1 in. See description in preceding list.

CHENANG, STRAWBERRY, 3/4 in., 1 in., and $11 / 2$ in. An old-fashioned, high-quality dessert apple ripening here about September I.

DHIICIOUS. I in.

IUCHESS OF OLDENBURG. 1 in. A redstripcd conking apple ripening in September.

lEARl.Y MclNTOSH. $3 / 4$ in. and 1 in.

FAMEUSE isnow Apple), $3 / 4$ in. An oldfashoned apple ripening in lare September.

MACOUN. I in. I new. dark red Mclintosh scedling varicty. (liery lew of the'c.)

IcINTOSH. $3 / 4$ in. and 1 in.

NORTHER.N SPY. $3 / 4$ in., 1 in. and $11 / 2$ in.

Vote.-Small sizes of the following varieties are avalable in small quantities at $\$ 1.00$ each:

Duchess of Oldenturg.

Gravenstcin.

Roxbury Russct.

Stayman Winesap.

Sweet Bough.

\section{PEARS}

Is desirable as apple trees and requiring less care. pear trees make an excellent investment. supplying shade, flower and fruit and increasing the value of your property.

Nways plant at least two varieties to insure cross-pollination.

Two-year, $5.7 \mathrm{ft}$ trees, $1 \mathrm{l} / \mathbf{1 6} \mathrm{in}$. caliper. Price $\$ 1.00$ each.

BARTLETT. Golden-yellow fruit, ripe by middle of September herc.

SHELDON. Round. russet pear. Juicy and delicious in late October

CLAPP'S liAVORITE: Yellow fruit with red check. I'ick in August before it softens and ripen in a dark cupboard.

SHCKEL. Tiny russet fruit pepular for cating and pickling. Late October.

FLEMISII BEAUTY. (Stoch limited. Give permisible substitute whon ordering.)

BFERRE BOSC. (Is above.)

I)WARF SECKEL. (As above.)

See Price Chart on page 3 if you are ordering more than one plant of a variety 


\section{CRAB-APPLE}

HYSLOP CRAB. The best. Fruit is large, brilliantly colored, dark red to purplish. I very. hardy tree and a good producer. Tall growing. Two-year, 5-7 ft., 11. 16 in. caliper. \$1.00 each.

\section{PLUMS}

Two-year, 5-7 ft. Price \$1.00 each.

ABUNDANCE. Large light pink fruit ripens late in July. One of the hardiest.

BURBANK. Large red canning plums on umbrellashaped tree. Inother variety should always stand near it.

LOMIBARD. Violet-blue European Plum. Bears young and heavily.

ST ANLEY. Prune type fruit for cooking or eating oul of hand. Ripens in September. A fine new variety.

IMIPERIAL EPIMEUSE, The epicure"s plum. Ripens late in September.

\section{QUINCE}

Lseful for inclusion in apple-sauce. Its tartness enhances the apple flavor.

Two-year, +-5 ft. Price $\$ 1.00$ each.

ORANGE. Large, round, golden yclless fruit. Ripens in early October.

\section{CHERRY}

Beautiful trees which enhance the landscape. The fruit is appreciated by everybody, including small boy's, tom boys and robins. As Sweet Cherries are not selfpollinating. at least two varietics should be included in every planting.

Two-year, 5-7 ft., 1116 in. caliper. Price $\$ 1.00$ each.

See Price Chart on page 3 for reduced prices or more than one.

\section{SWEET VARIETIES}

BLACK TARTARIAN. Bright purplish-biack. large fruit. Becomes a large tree.

GOVERNOR WOOD. lellow and red frnit on a very hardy tree.

WINDSOR. Dark, late fruit of excellent quality: Good grower and productive.

\section{SOUR VARIETIES}

EARLY" RICHMOND. The gond, old, liardy" variety, Red fruit in June.

ENGIISH MORELLO. Mnost black red fruit. ripens in late July. Tree is small at maturity.

MONTMORENCY. Large sized. clear led fruit. ripens abundantly carly in July. The most popular sour cherr!.

\section{SEMI-SWEET VARIETY}

MAY DUKE. Early, hardy and popular. I.arge red fruit and lots of it.

\section{PEACHES}

These are the hardiest varieties. They do not bear every year here. but do so often cuough to be worth raising. They grow rapidly.

One-year, 4-5 it. $75 \mathrm{c}$ each.

ORIOLE, Jellow freestone. I new, early, laardy sort. Excellent.

BELLE OF GEORGIA. White freestone. Res. theeked and rugged. September.

CARIIAN. White freestone. Reliably liardy. ripening in lale dugust.

ELBERTA. The ontstanding peach. Yellow freestune. It ripens in mid-September.

\section{APRICOTS}

Apricots blossom even before Plums in the Spring and are ornaments in any situation. They can be grown successfully farther nortli than Peaches. Plant two varicties for crosspollination. The fruit rijens in mid-Summer.

$$
4.5 \text { ft. trees. } \$ 1.00 \text { eacls. }
$$

EARLY GOLI)EN. Medium, pale orange, swew fruit.

MOORPARK. Deep yellow with red check. It hat the best quality and flavor of all Ipricuts.

\section{GRAPES}

Grapes thrive on medium, well drained soil. They should be set eiglit feet apart. Vines last a lifetime.

Two-year. No. 1. Price the each.

CONCORD, Blue. The favorite. Nit relishly hardy north of Massichnscus except along the scist. Ripen in late Scptember.

WORDEN. Blue. Similar to Conard but a weeh earlier. Better for the North.

FREDONIA (New). The bes early black grape. lines are vigorous, lardy and productive. Farls September.

DELAWARE. Red. In old favorite. Bunche. and grapes are small but sweet and deliciou. Early October.

CACO. Red. I new, wire-rea, larke, sweet grape. Mid-Septenuber.

NIAGARA. White. The must penular white grape. lïgorous and productive. I.ate September. PORTI.ANI). Greenishowlite. l-arge bunches and berries. Ilardy. Iery early.

\section{See Price Chart on page 3 if you are ordering more than one plant of a variety.}




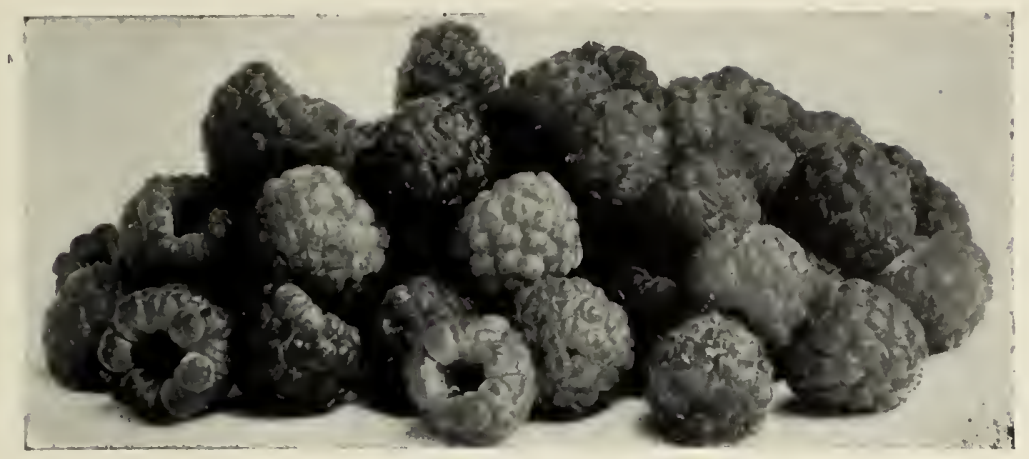

\section{REI) RASPRERRIES}

\section{RASPBERRY PIANTS}

Viot only are Rasplerries one of the most alelicious berries for lome use. but they are alse) one of the safest to plant commercially. In murc than twenty years of growing Raspherries. we have always had a market for all we produced.

Plant on good, nell drained soil, on a slope if possible. and cultivate freely. Fertilize with chemicals and wood ashes rather than manure. except that poultry manure is good if you have it. Of the red varieties from 2.(1)1) to 3.000 plants per acre are required. planted 21/2 to 3 feet apart in rows 6 feet apart. The black and purple varictics. pitnted 3 feet apart in rows 7 feet apart. require about 2.000 plants per acre.

\section{B.-Price Chart does not apply on} Raspberries.

L.ATIAM (Ked). The leading commercial variety. brect canes, very hardy, a heaby yielder and good - hripner. Fair quality. 75 c per $12 ; \$ 1.50$ per 25 : $\$+.50$ per $\$ 100 ; \$ 35.00$ per 1,000 .

VFWBURGH (Red). The licaviest yielding and hardiest of all raspberries. Bears heavy crops of immenve berries in mid-season. Fruit is good yuality and very firm, making a good shipper. Diseuse-resistant. Medium height, 75 c per 12; $\$ 1.50$ per $25 ; \$ 5.00$ per 100 .

TAYLOR (Red). A new, early; extremely dehicinus raspberry. High quality. Iluge berries throughour the season. Fixcellent for home use and lacil sale. 75c per $12 ; \$ 1.50$ per $25 ; \$ 4.50$ per 100 ; $\$ 35.00$ per 1,000 .

PLUM FARMER (Black). Our finest "black(גp" raphersy, ripening early. Tip-plants, $75 \mathrm{c}$ per 12; \$1.50 per 25; $\$ 4.50$ per 100 .

COLUMBIAN (Purple). Tip-plants, $75 c$ per 12: $\$ 1.50$ per 25: $\$ 5.00$ per 100 .

\section{STRAWBERRY PIANTS}

\section{N. B.-Price Chart does not apply on Strawberies.}

IHOWARD 17 (Premier). Early. Panluces larke quantities of large. allractive. luscions berries. Grows well on light soils and stands dry weather better than some. 'This is the variety most plantecl. $\$ 1.00$ per $50 ; \$ 1.50$ per $100 ; \$ 12.00$ per 1.000 .

CATSKILL. Midseason. Immense quantities of fine fruit on large, vigurous plants. Widely adapted (1) soil and climate. Calskill is a sure cropper. $\$ 1.00$ per $50 ; \$ 1.50$ per $100 ; \$ 12.00$ per 1.000 .

GREFN MOUNTAIN EVERBEARING (Patented.) (Originated at these nurseries. Inder the patent you are permitted 10 grow as many new plants as you wish for your own use. Before growing plants to sell or otherwise distribute, arrangements nust be made with us.) This finest of all the fall-bearing varieties we have tried produces large, firm, bright red frut of extra quality. The plants which are vigorous and extremely resistant 10 disease, do better in fairly heary soils than in light orres. P'ick off blossoms the first Sunmer until - ligurat first. Runner plants, $\$ 2.00$ per $50 ; \$ 3.50$ per $100 ; \$ 20.00$ per 1,000 .

\section{BLACKBERRY PLANTS}

SNYIER. 75 c per $12 ; \$ 1.50$ per $25 ; \$ 4.00$ per u).

\section{NUT TREE}

BUT'TERNUT. The welt-kiown northern nut tree from which many thousands of rich nuts are gathered every year. Entirely hardy. They require a long time to come into bearing, but are worth witing for.

4 ft. trees. \$1.50 each.

See Price Chart on page 3 if you are ordering more than one plant of a variety. 


\section{PERENNIALS FOR COLOR}

These hardy flowering plants will brighten your borders and provide color and interest all through the season. Color, height and blossoming season of each species or variety is given after its name.

Thirty-five cent each, except as otherwise noted. For reduced rates on small as well as large quantities, see the Price Chart on page 3.

ACHILLEA

The Pearl. White. 12 in. Summer.

Tomentoss. Yellow. 10 in. July.

ACONITUMI

Fisheri. Blue. 3-4 in. September-November.

Napellus. Dark blue. 3-t in. July-August.

Spark's Variety. Dark blue. 2-3 in. JulyAugust.

ADONIS

Vernalis Yellow 12 Spring Adoni (3 for $\$ 1.25$ ).

AJUGA

Reptans. Purple, creeping. Spring.

ALTHEA ROSEA

Double red, yellow, pink (Newport pink) or white. Order by color. July-August. $31 / 2$ ft. 30 c each.

ALYSSU.M

Saxatile citrinum. Yellow, 6-8 in. May.

Serphyllifolum. Lemon yellow. Prostrate. May.

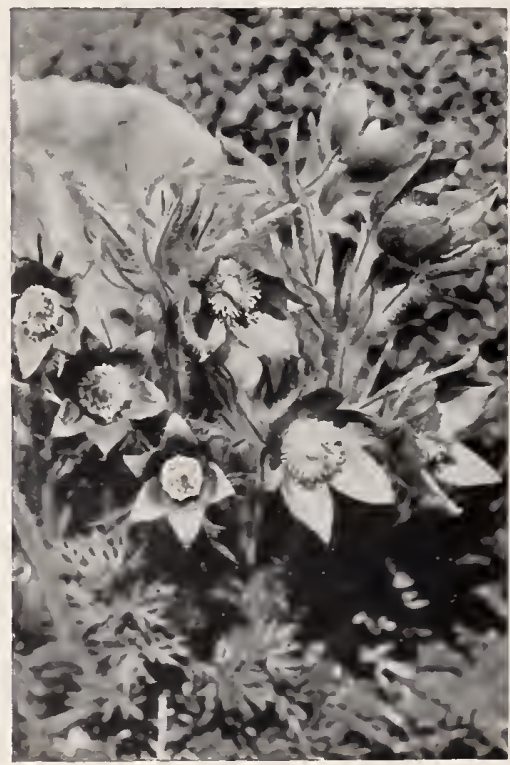

ANEMONE PULSATILLA
ANE.IONE

Canadensis. Wbite. 9 in. May-June.

Whirlwind. Double white. $21 / 2 \mathrm{fr}$. September. Pulsatilla. Lilac-blue. 6-8 in. April.

\section{A.NTHERICUंM}

Liliago. White, 2-3 r. July.

AQUILEGIA

Caerulea. Blue. 18 in. Mav.

Canadensis. Red-yellow. 1-2 ft. May-June.

Chrysantha. Gold. 18 in. May-Iune.

Mrs. Scott Elliott. Mixed. $2 \mathrm{ft}$. May-June.

ARABIS

Rock Cress

Alpina flore-pleno. Double white, $S$ in. May.

ARENAKIA Sondwors

Montana. White, 4 in. May-Junc.

ARTEMESIA

Abrotanum (see llerb section). 30c each.

Lactiflora. White. 4.5 $\mathrm{f}$. September, $35 \mathrm{c}$ each.

Absinthium (sec Herb section). 30c each.

Stelleriana (see Herb section). 30c each.

ASTER

Michoelmos Doisy.

Alpinus. Blue or white. 9 in. May-June.

Harrinkton Pink. Pink. 2-4 ft. September.

Hybridus luteus. Yellow. $3 \mathrm{fr}$. August-Septen: ber.

Victor. Dwarf lavender. 8 in. September.

ASTILBE Herboceous Sipirea Kriemhilde. Salmon-pink. $3 \mathrm{ft}$. Sumner. $40 \mathrm{c}$ cach.

AUBRIETIA.

Delfoides. Nixed colors. $6 \mathrm{in.} \mathrm{Mlay.}$

BAPTISIA

Wild Indigo

Australis. Blue, $3 \mathrm{ft}$. June.

Bracteata. Creamy wite. Is in. May-Junc.

Tinctoria. Fellow. 2 fe. Angust.

BOLTONIA Boltousa Latisquama. Lavender-pink. 4 f. BufuspSeptember.

CAMPANULA

Bcllfioner

Carpatica. Blue. 6 in. July-September.

Carpatica alba. Whitc. 6 in. July-Septesnber. Persicifolia. Blue. $3 \mathrm{ft}$. July-dugust,

Persicifolia. White. i ft. July-Austist.

CENTAUREA

Montana. Blie. $2 \mathrm{ft}$. June.

Cornfiozer

CERASTIUMI each.

CEPIIALARIA

Cepholorio

Tatarica. Crean yellow. $6 \mathrm{fr}$.

CHELONE:

Lyoni. Roce-pink. 3 ft. August.

Tirtlehcod

Thirty-five cents each, except as otherwise noted. For reduced rates on small as well as large quantities, see the Price Chart on page 3. 


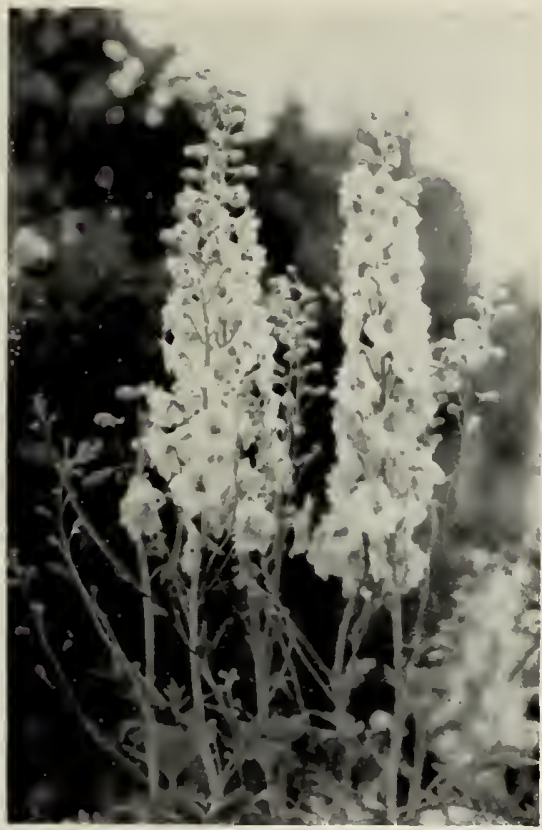

\section{DELPHINIUM HYRRIDS}

CHRYSANTIIEMUMS Hardy Chrysonthenums Ardenteuillais. Red. Decorative.

Early Bronze. Bronze pompon. I 1 / ft. September.

Judith Anderson. Yellow pompon. $11 / 2 \mathrm{ft}$. October.

October Girl. Lavender-pink, semi-duuble. $11 / 2$ it. October.

IIars. Deep red, single. $21 / 2-3 \mathrm{ft}$. October.

Hebe. Silvery-pink to lavender, single. $2 \mathrm{ft}$. September.

Daphne. Old rose, single. $2 \mathrm{l} / 2 \mathrm{ft}$. October.

Astrid. P'ink. ("Northland Daisy"). I1/2 ft. October. Very hardy.

Cushion Mums. August-October.

Pink Cushion. Pink.

Red Cushion. Red.

King Cushion. Red to bronze.

CHIRYSANTIIEMUUI

Maximum. White. 18 in. Summer.

COI.CHICUM

Autumnale. Lavender-pink, 8 in. Fall.

CONVALLARIA

Lily-of the - Yolley

Majalis. White. 6 in. Spring. Pips, $\$ 1.00$ per 12.

Rose. Pink. 6 in. Spring.

COREOPSIS

Lanceolata. Yellow. 2-3 ft. All Summer.
DELPHINIUM Hardy Larkspur

Belladonna. Blue. $3-5 \mathrm{ft}$. June.

Bellamosum. Dark blue. 3.5 ft. June.

Tom Thumb. Copenhagen blue. 12 in. June. Pacific giant hybrids. Blue. 5-6 ft. JuneSeptember.

Wrexham Strain. Mixed sliades. 4-6 ft. June.

DIANTHUS BARBATUS Siz'et Hilliom Mixed colors.

DIANTHUS Pink Plumarius (Grass P'ink). Pink. I ft. June. l'lenus (J)uble Scotch plunks). Mixed. I ft. June.

Hybrids, Pink, I ft. June, 25c each.

I)ICENTRA Bleedine Heart Eximea. Red. 12 in. lll Summer

Spectabilis. Pinh. $2-2 \mathrm{~d} / 2 \mathrm{ft}$. Nay-June. $50 \mathrm{c}$ each.

IICTAMNUS Gas Plant

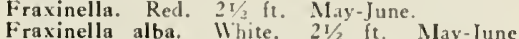
Fraxinel

DIGITALIS PURPUREA GLOXINIAEFOLIA

Alba. White. 4-5 ft. June.

Foxplove Rosea. Pink, 4-5 ft. June.

DODECATHEON

Shooting Star Meadia. Rose-purple. $[1 / 2 \mathrm{ft}$.

Coneflower ECHINACEA

I'urpurea. Purple. $21 / 2 \mathrm{ft}$. Spring and Fall.

ECIIINOPS Giobe Thistle Ritro. Metal-blue. 2 ft. June.

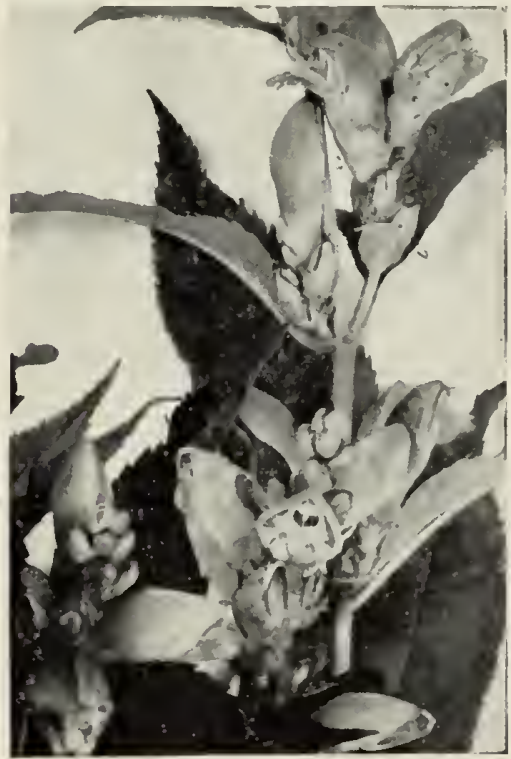

CHELONE LYONI

Thirty-five cents each, except as otherwise noted. For reduced rates on small as well as large quantities, see the Price Chart on page 3. 


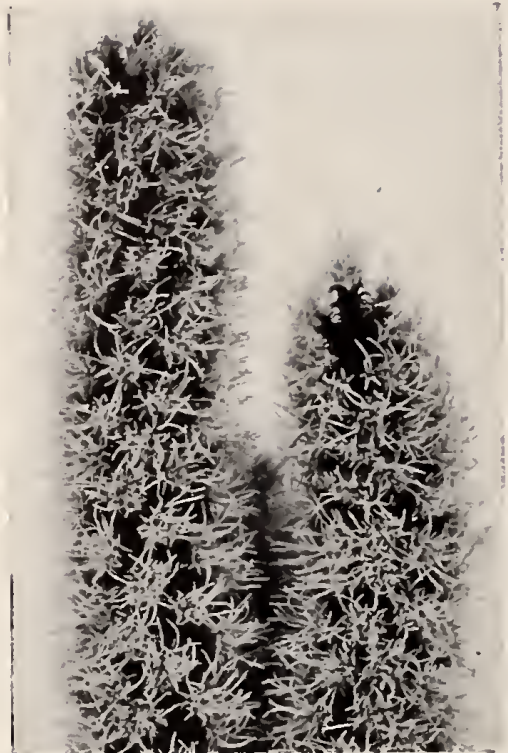

LIATRIS SPICATA

HUPATORIUNI

Hardy Argeratum Coelestinum (Mlist-fower). Blue. $2 \mathrm{ft}$. Jugust.

EUPHORBIA

Corallata, Wlite. $2 \mathrm{ft}$. Late Summer.

Spurge

FILIPENDULA Meadare Sicert Hexapetala. Wilite. $2 \mathrm{ft}$ July:

FUNKIA (see "IIosta").

GALLARDIA Blanket Flawer Grandiflora. Red and yellow. 2 ft. 111 Summer. Sun God. Yellow. $2 \mathrm{ft}$. All Summer.

G)PSOPHILA Baby's Breath Paniculata. Feathery white. $3 \mathrm{ft}$. July.

Bristol Fairy. Double white. ; ft. June-Iuly and Autumn. $50 \mathrm{c}$ eacb.

Repens. White or Rose, 6 in. Iuly and luguss.

HELIANTHEMUM CHAMAEUSTUS Sun Rose Mutabile. Hixed colors. 12 in. June-July.

HELIANTHUS Perennial Sunflater Divaricatus. Yellow. $6 \mathrm{ft}$. Late Summer.

HEMIEROCALIIS

Flava. Lemon-yellow. 2-3 ft. June.

Fulva. Orange-red. 3-j ft. Julv.

Middendorfi. Pale oranse. 18 in. July-ligu-?. Tbunbergi. I emon-vellow. 2-3 ft. Juls

Betseber's bybrids. Iariable.

Orange hybrid. 30 c encb.

HEUCHERA

Coral-Bells

Sanfuinea. Coral-red, 12-18 in. June-July.

Rosamundi, Coral-pink. 12-18 in. June-July
HIBISCUS

Rose. Wallaie

Noscbeutos. Rane-pink. \& ft. July-lugus.

New Giant-flowering. Ilixed nink, white se:

4 ft. July-.lugus.

HOSTA (Funkia) Aurust Lily or Planfajulily (Funkia).

Caerulea. Blue. $11 / 2$ f1. Sumner.

Plantaginea. Wlite. $11 / 2-21 / 2 \mathrm{ft}$. late Snmmet.

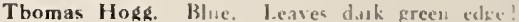
white.

IBER IS

Hardy Caudyute

Sempervirens. Whice I? in. May-June.

\section{IRIS}

Flavissima (Irenaria). Canartyelluw, Mur:ature.

Pseudacorus. Ricl yellaw. $3 \mathrm{ft}$.

Prismatica. loilet and rellow. To ; $\mathrm{ft}$.

Pumila atroviolaceae. Purple anil blue, I ft May.

Sibirica. Deep bluc. ift. July.

Sibirica (Snow Queen). White. ; ft. July.

Sibirica. (Perry's Blue). Clear blue. \& fo. Mulv.

Sibirica (Emperor). Blue. 3 fe. July.

IRIS GERMANICA

Bearded Iris

Mixed varieties witbout labels. $2(1 \mathrm{c}$ each.

(See Price Cbart on page 3 fur low quantu?! rates.) On request we shall send a lint of nanie. varieties and their prices.

IRIS KAEMPFER I

Oriental Iris

Faseination. Lavender, rose and white.

Gold Bound. Snow white, yellow marking.

Pyramid. Light blıe, six petals.

Maboßany, Rich velvety red.

\section{LIATRIS}

Blazing Srar Scariosa. Bluish-purple. it ft. Lugust-Septer. ber.

Spicata. Lilic-rose. $\quad+\mathrm{ft}$. Lusun-Septemler.

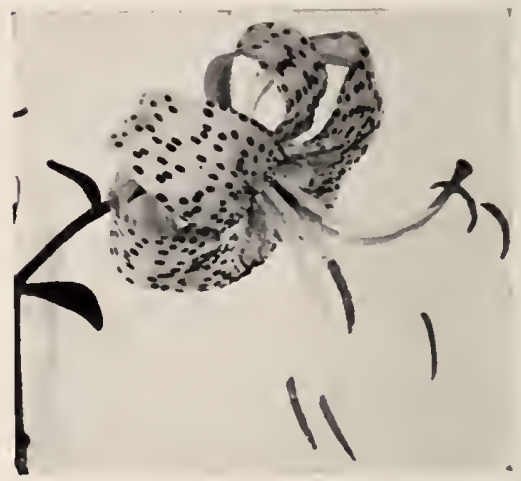

\section{LILIUM TIGRINIUM}

Thirty-five cents each, except as otherwise noted. For reduced rates on small as well as large quantities. see the Price Chart on page 3. 


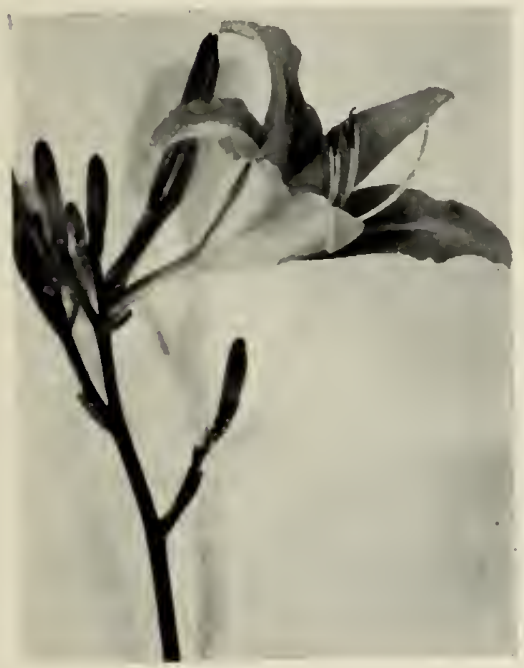

IIEMEROCAI.IS FUIVA

1.11. IU. II

Candidum (Maclonna 1..). 40e each.

Regale (Regal I..).

Tigrinum (Tiger 1.).

Tenuifolium (Siberian Coral 1..).

Superbum (Turk's Cap).

(See "Wildnower" section for native sprecies.)

I.IMIONIUMI

Sea Lazender Latifolium. Blue aml white. J-11/2 fi. July. lugust.

I.INUM

Perenne. Bltie. Is in. Ill Summer.

Flax

I, YCHNIS

Chalcedonica. Scarlet. 21/2 ft. July- Iugust. Viscaria. Punk. 18 in. June.

I. ISIMACHIA

Punetata. Yellow. : ft. Juls.

IIONARDIA

Didyma. Red. ; fe, huly

Didyma rosea. Rose-pink. ; ft, 50c each.

Fistulnsa. Lilac-purnle, ; ft. July.

()ENOTHERA

Evening Primsose

Missouriensis, Yellow, 6-12 in. Iune July.

()PUNTIA

Johnson's. Yellew. Sunnuer. 25e each.

PACIVSANDRA TER.NINALIS

livergreen ground inver. 25e each.

P'AEONIA

Spurer

\section{Fixtral strong torst:}

Nhatre, White. $40 \mathrm{c}$ each.

Asa Gray. Lilac, pinh. 50e each.

Crown of Gold. White with gold stamen 40 c each.
Edulis Superba. 1'ink. 50) each.

Felix Crousse. Brilliant ted. 60e each.

Festiva maxima. White. flecked scarlet boe each.

Solange. Creamy salmon. 90c each.

Milton Hill. Flesh pink. \$1.00 each.

Mme. D. Treveran. White, intesl laventer 90e each.

Longfellow. Crimon, 90e eneh.

Ime. Emile Galle. Shell pink, 40e each

Mme, de Verneville. 30e each.

Primevere. Cream, with yellow center. 90 e each. Rubra Superba. Real. 50e each.

By color, not named, red, white or nink 3.5e each.

Mlived coliors, not named. 30e each.

PAPAVER

Pilosum (Olynpic I’.). Apricot-pink. 2-j ft.

Orientale. Orange varictics. 2-3 fr. June

Orientale. Red variety. 2-3 ft. June.

Orientale (Mrs. Perry). Old rone, June

PENSTEMON

Beard-Tongue

Torrevi. Scarlet, i ft, Puly-lugust.

Digitalis. White. Is in. July.

Hirsutus. Violet, $3 \mathrm{ft}$. Julv.

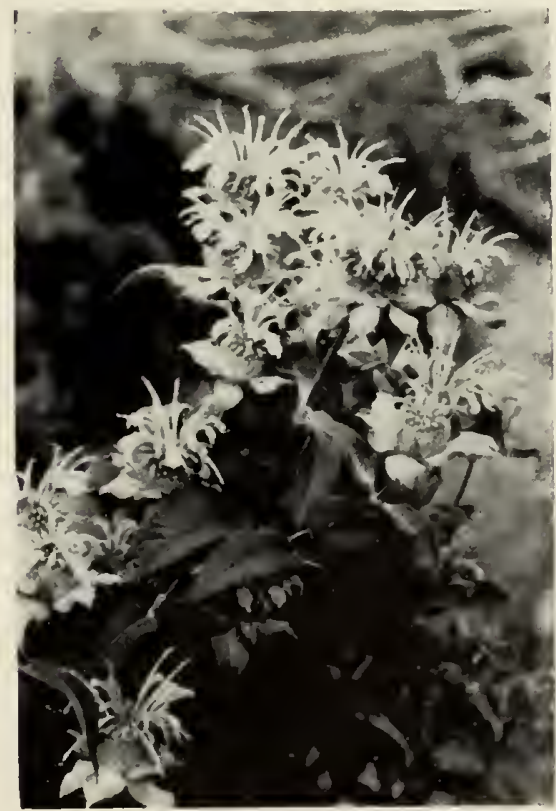

\section{MONARDA DIITYMA}

Thirty-five cents each, except as otherwise noted. For reduced rates on small as well as large quantities. see the Price Chart on page 3. 


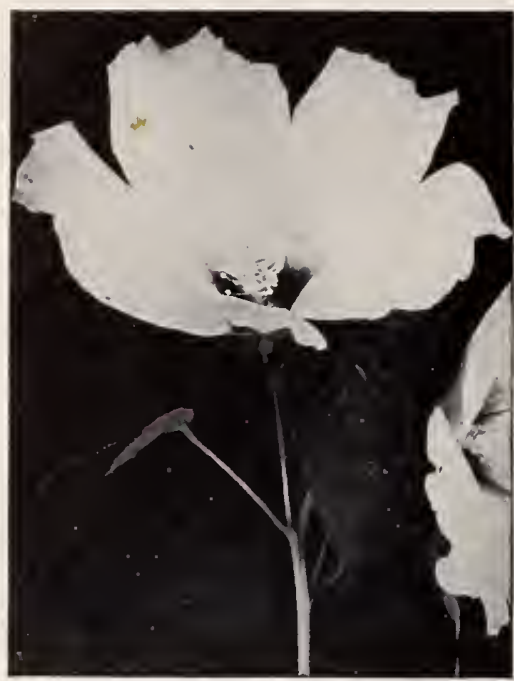

HIBISCUS-MALLOW

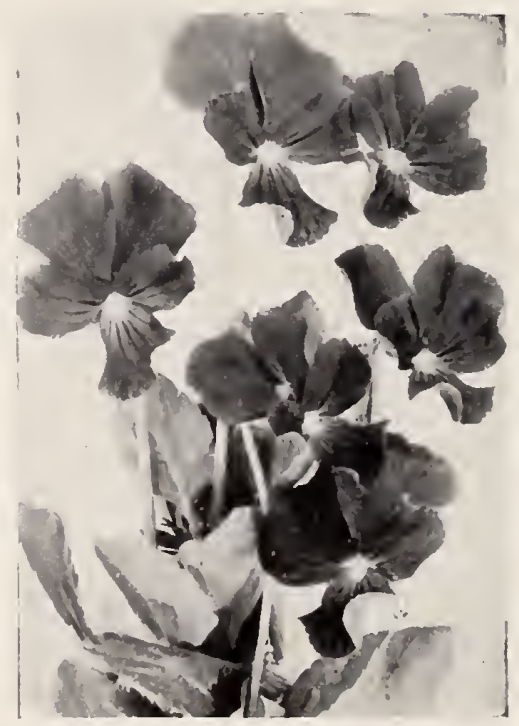

VIOLA JERSEY GEM
PHLOX DIVARICATA. (See "Wildflower" sec(ion.)

PHLOX PANICULATA Varieties Garden Phlox

Anton Mercier. Blue. $30 \mathrm{c}$ each.

B. Compte. Crimson, 30e each.

Commander.

Enchantress. Salmon-pink. 30c each.

Ethel Pritehard. Blue-mauve. $30 \mathrm{c}$ each.

Elinor Cardell.

Frau Anton Buehner. Pure white.

Jules Sandeau. Clear rose.

Leo Sehlageter. Brilliant scarlet.

Martin's Pink. P'ink. 30e each.

Painted Lady. Shell pink, red eyce. 30c each.

Riverton Jewel.

R. P. Struthers. Flame color. 30c each.

Saladin. Orange-scarlet.

Salmon Glow. Salmon pink.

PHLOX SUFFRUTICOSA green and discase free. $40 \mathrm{c}$ each.

PHLOX SUBULATA

Blue, white or pink. 6 in. May.

Apple blossom. $6 \mathrm{in.} \mathrm{May.}$

PHYSALIS

Franeheti. Orange-red fruit in Fall. 2 ft.

PHYSOSTEGIA False Dragon-Head

Virginiana. Pink or white. 3-4 ft. August.

Vivid. Deep pink. 12 in. August-September.

PLATYCODON GRANDIFLORUM

Album. White. $21 / 2$ ft. July-August.

Balloan Flower

Mariesi. Blue or white. $1 \frac{1}{2} \mathrm{ft}$. July-August.

POLEMONIUM

Caeruleum. Blue. 2-3 $\mathrm{it}$.

Jacob's Ladder

PRIMULA Primrase

Japonica alha. Snowy white. 2 ft. June. $50 \mathrm{e}$ each.

Hose-in-hose. Ycllow with orange cye. Rare. $50 \mathrm{c}$ each.

Veris. Yellow. Fragrant. 6-8 in. May.

Vulgaris. Yellow, $4-6$ in. April-ilay.

PYRETHRUM (Chrysanthemum) Painted Daisy Roseum. Pink. Is in. June.

SAPONARIA

Oeymoides. Pink. Trailing. May-Junc.

SCUTELLARIA Skull Cap

Integrifolia. Bluc. 11/2-21/2 ft. Iugust.

SEDUM Stonecrop or Lize-Farever Acre. Yellow. 4 in. May-June.

Dasyphyllum. Pinkish white. 2 in. Farly.

Summer.

Kamschaticum. Yellow, 6 in. July-August.

Sarmentosum. Yellow: 4 in. May-July:

Mixed varietics. 25e each.

SEMPERVIVIUM Hens and Chickens

Rubicundum (blandum). Red. 25c each.

Triste. Red. 25c each.

STOKESIA

Cormflazer Aster

Cyanea. Blue. 18 in. All Summer.

Cyanea alba. White. 18 in. All Summer.

THALICTRUM

Glaucum. Yellow: \& ft. Junc-July.

Mlartin's Yellow.

Minus. Fernlike foliage. 12 in.

Polygonatum. Sulphur yellow. $21 / 2$ ft. JuneJuly.

Thirty-five cents each, except as otherwise noted. For reduced rates on small as well as large quantities, see the Price Chart on page 3. 


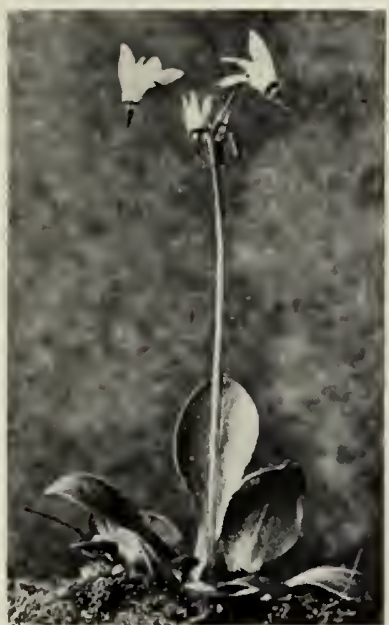

DODECATHEON

(Shooting Star)

THEKMIUPSIS Caroliniana. Yellow. $t$ ft. June.

TRAIESCANTIA 18 in, Spiderwort Virśiniana rosea. Pink. 18 in. June-July. 25 c each.

TROLLIUS

Ledebouri. Deep sellow. 2 ft. May:

TUNICA Saxilraga. Pink. 10 in. June-July:

IFRBASCUM

IERONICA

Incana. Bluc. 8-12 in. $|u|_{y}$.

Incana rosea. Pale pink forin of the above.

Prostrata. Blue. 6 in. May-June.

Repens. Blue. 3 in. May-June.

Teucrium. Blue. 12 in. June.

Virginica. White. Tall. August.

IINCA MINOR Periankle or Myrle Bowle's Variety. 40c each.

VIOLA Tufted Pansies Jersey Gcm. Violet-blue. 6-8 in. All Summer.

VIOLA ODOKATA of which our stock is limited. $50 \mathrm{c}$ each.

(For native species of liolets, look on the "Wildflower" pares.)

I LCCA

Adam's Veedle lleavy clumps. $50 \mathrm{c}$ each.

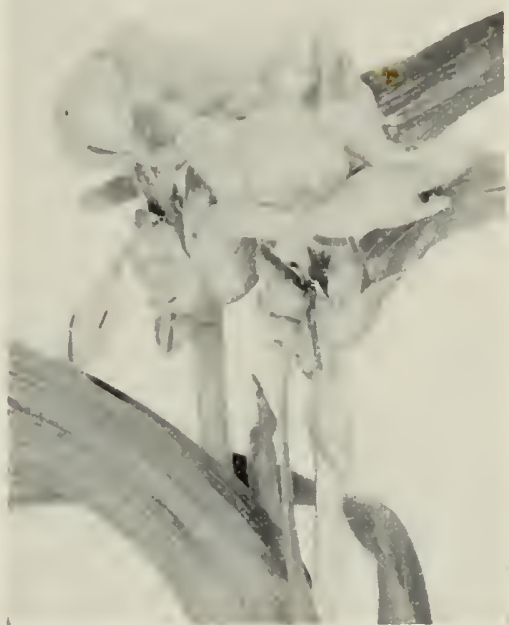

TRADESCANTIA VIRGINIANA

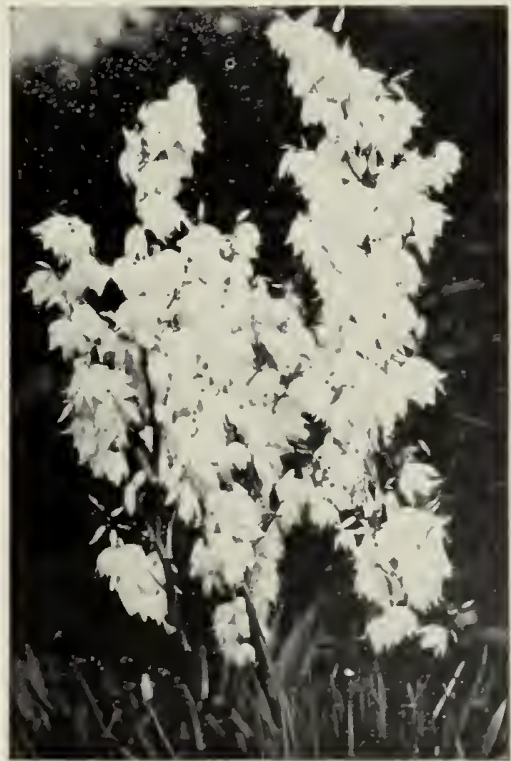

YUCCA

Thirty-five cents each, except as otherwise noted. For reduced rates on small as well as large quantities, see the Price Chart on page 3. 


\section{Flowering Shrubs}

\section{DECIDUOUS AND EVERGREEN}

For cost of two or more of the same variety at the reduced quantity rates consult the PRICE CHART on page 3. Prices shown below are for one plant. (BAB means "Bailed and Burlapped.")

ALLEGHENY SHADBLOW Amelanchier laptis. 3-4 ft. $\$ 1.00$ each.

SWEET AZALEA, Azaleo orborescens BAB. 3.4 ft. $\$ 3.50$ each; 4.5 ft. $\$ 4.00$ each.

FLA.ME AZALEA, dzaleo colendulaceo. Bib. 3.4 ft. $\$ 3.50 ; 4.5$ ft. $\$ 4.00$.

PINKSHELL. AZALEA, Azoleo voseyi. B太B $3.4 \mathrm{ft}$. $\$ 3.50$.

SWAMP AZALEA, Aaleo viscoso. BAB. 2-3 ft. $\$ 2.00 ; 3.4$ ft. $\$ 3.00$.

O.X-EYE BUTTERFLY BUSH, Bnddleia daridi mognifico. Strong plants. 50c each.

Buddleio, CH.IR.VIIG (pink). Strong plants. $60 \mathrm{c}$ each.

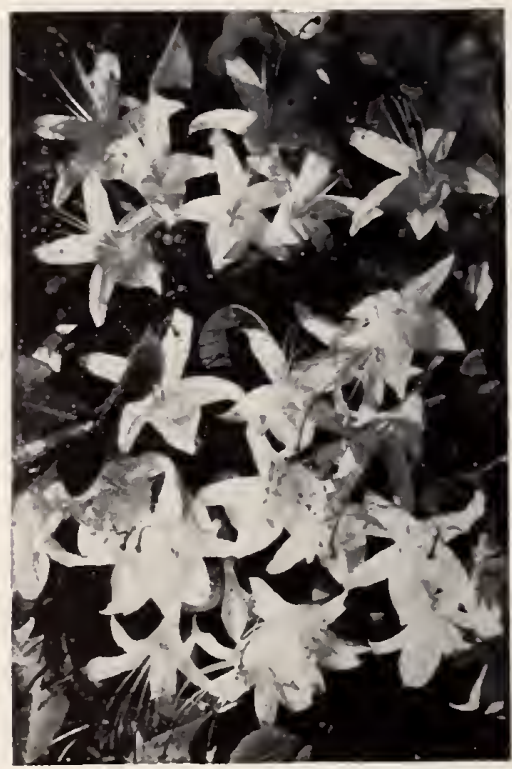

A ZALEA
SWEETSHRUB, Calyconthus floridus, 18-2t in. $60 \mathrm{c}$ each.

SIBERIAN PEA-TREE, Caragono arborescens. $3-4$ ft. $75 \mathrm{c}$ each; $4-5 \mathrm{ft}$. $90 \mathrm{c}$ each.

I)WARF PEA-SIIRUB, Caragona pygmaeo. 18-24 in. $75 \mathrm{c}$ each.

WHITE FRINGE TREE, Chionanshus virginica. 2.3 ft. $75 \mathrm{c}$ each.

SUMMERSWEET, Clethro alvifolio. 18.24 in. $60 \mathrm{c}$ each: $2-3 \mathrm{ft}$. $75 \mathrm{c}$ each.

FLOWERING QUINCF, Cydonio joponico 2. $21_{2}$ ft. $75 \mathrm{c}$ each.

GARLAND FLOWER, Daphne cueorum. BAB 6.9 in. (spread) $75 c$ each; 9.12 in. $\$ 1.00$ each: 12.15 in. $\$ 1.50$ each.

FEBRUARY" DAPHNE, Daphne mezereum, BAB. $12-15$ in. $90 \mathrm{c}$ each.

WINGED EUONIMUS, Enonymus alotus. IX. 24 in. $60 \mathrm{c}$ each.

EUROPEAN BURNINGBUSH, Euonymus enropoens. $2.3 \mathrm{ft}$. $60 \mathrm{c}$ each; $3-4 \mathrm{ft}$. $75 \mathrm{c}$ each.

WINTERCREEPER, Enonymus rodicons. Sitrong plants. $60 \mathrm{c}$ each.

BORDER FORSITHIA, Forsythio spectabilis. $2-3$ ft. $60 \mathrm{c}$ each: 3.4 ft. $75 \mathrm{c}$ each; $4.5 \mathrm{ft}$. (extra busliy) $\$ 1.00$ each.

WEEPING GOLDEN BELL, Farsythia suspenso. 2-3 ft. $60 \mathrm{c}$ each; $3-4$ ft. $75 \mathrm{c}$ each.

SNOWHILL, HYDRANGEA, Hydrangeo orbores. rens. 2.3 ft. 75 c each.

PEEGEE HYDRANGEA, Hydrongeo poniculotn. 2-3 ft. $75 \mathrm{c}$ each; tree form, 3-4 ft. \$I.50 each.

MOUNTAIN I.AUREL, folmio lotifolio. BAB. 18.24 in. $\$ 2.50$ each.

DROOPING LEUCOTHOE, Leucothoe colesboei. A graceful, low, evergreen shrub especially useful for planting with Me. Laurel and Rhododendrons. Foliage turns mahogany red in Winter. Clusters of fraprant, white flowers in Spring. BAB. 18.24 in. $\$ 1.75$ each; 2-3 ft. $\$ 2.50$ each.

A.MUR PRIVET, Ligustrum amurense. $2.3 \mathrm{ft}$. 30 c each.

IBOLIUM PRIVET, Ligustrum ibalium. 2-3 ft. $30 \mathrm{c}$ each.

Special-Threc-year plants cue back last year t" form extra buxhy tops, $12-18 \mathrm{in.} 40 \mathrm{c}$ each.

For price of quantitics, sce Price Chart on page; TAT ARIAN HONEYSUCKI.F, Lonicero safarica. $2.3 \mathrm{ft}$. $75 \mathrm{c}$ each.

See Price Chart on page 3 if you are ordering more than one plant of a variety. 


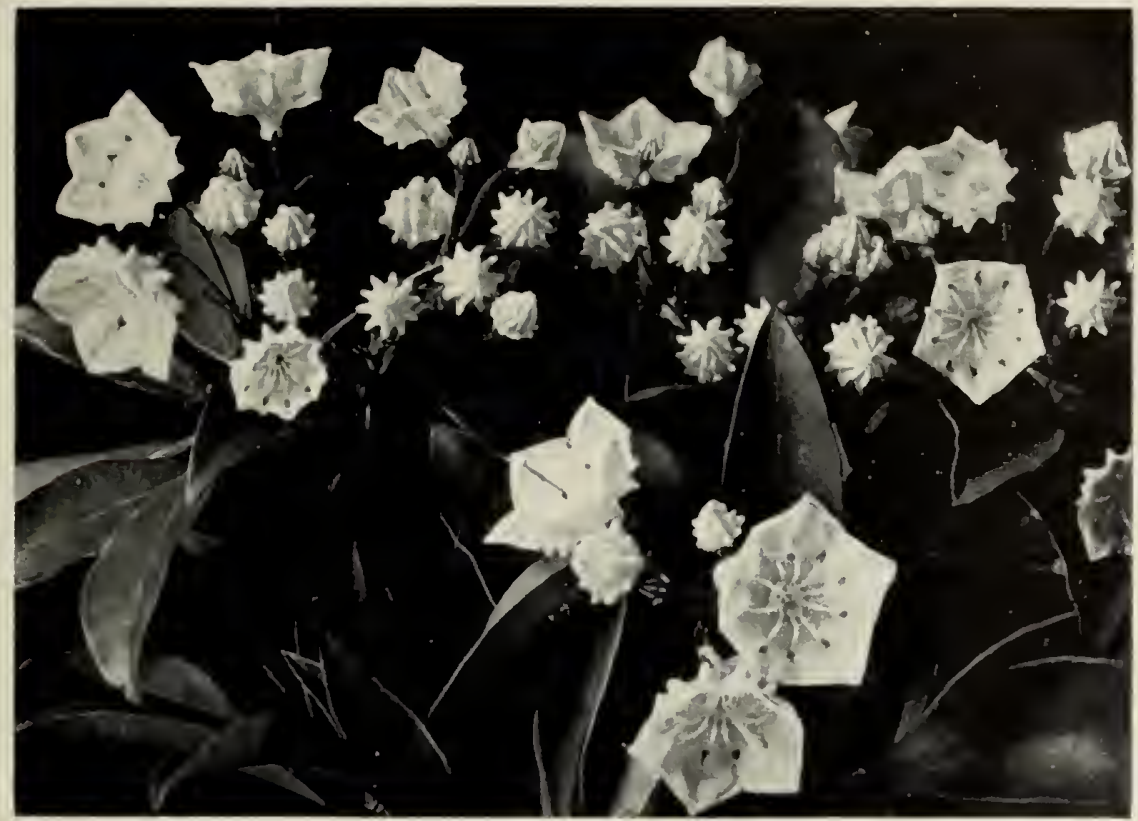

WOUNTAIN IAUREI.

CANBY PACIISTIMA, Pachystima canbyi. 8.10 in. $75 \mathrm{c}$ each.

SWEET MOCK ORANGE, Philadelphus coro. narins. The uld-fashioned. fragrant "Siringa." 2-3 ft. $60 \mathrm{c}$ each.

VIRGINAL, MOCK ORANGE, Philadelphus vireinale. $2.3 \mathrm{f}$. $75 \mathrm{c}$ each.

GOLILEAF NINEBARK, Physocarpns apulifolins luteus. I b.rgain! 4.5 It. 75 c each.

IOUNTAIN ANDROMEDA, Pieris flaribunda. $18-2+$ in. $\$ 3.50$ each; $2.21 / 2$ ft. $\$ 4.00$ each.

SHRUBBY CINQUEFOIL, Patentilla fruticasa. $15-18$ in. $60 \mathrm{c}$ each.

PURPI,E-LEAF SAND CHERRY, Prnns cistena. Cisusual. (Only a few for sale. 2.3 ft. 90c each.

NANKING CHERRY. Prnus tamensasa. Edible fruit. $2-3 \mathrm{ft} .75 \mathrm{c}$ each.

FLOWERING; PLUM, Prunus trilaba. $3.4 \mathrm{ft}$. $\$ 1.00$ each.

GI.OSSY BUCKTHORN, Rhamms frangula. $5-6 \mathrm{ft} . \$ 1.00$ each.

CAROI.INA RHODOIENDRON, Rhadodendran raralinianum. B\&B. I5.18 in. $\$ 2.00$ each; 18.24 in. $\$ 2.50$ each: $2.3 \mathrm{ft}$. $\$ 3.50$ each.

RHODODENIDRON CAROLINIANUM AL. BU.M (White). BAB. 2-3 ft. $\$ 4.00$ each; 3.4 ft. $\$ 4.75$ each.

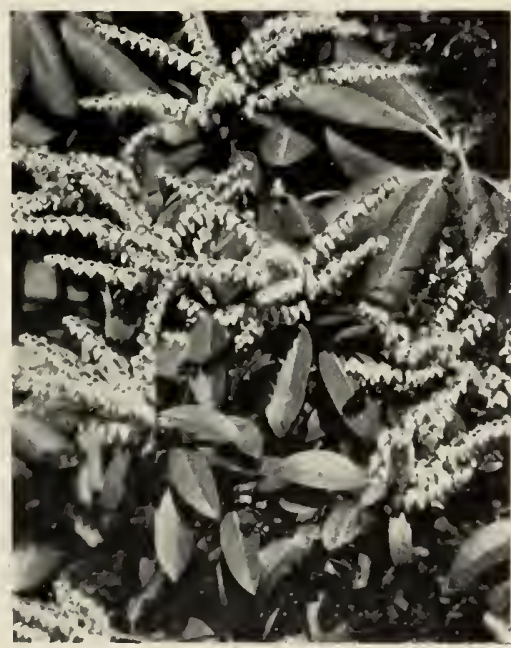

PIERIS FLORIBUNDA

See Price Chart on page 3 if you are ordering more than one plant of a variety 


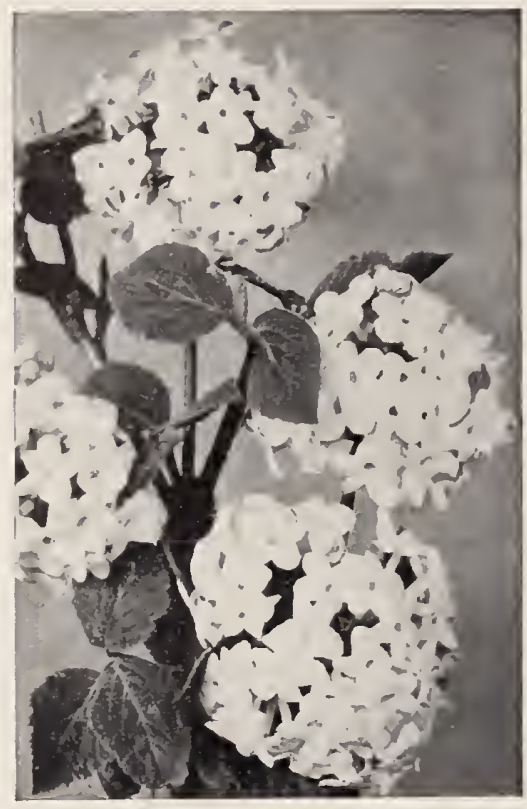

VIBURNUM CARLESI

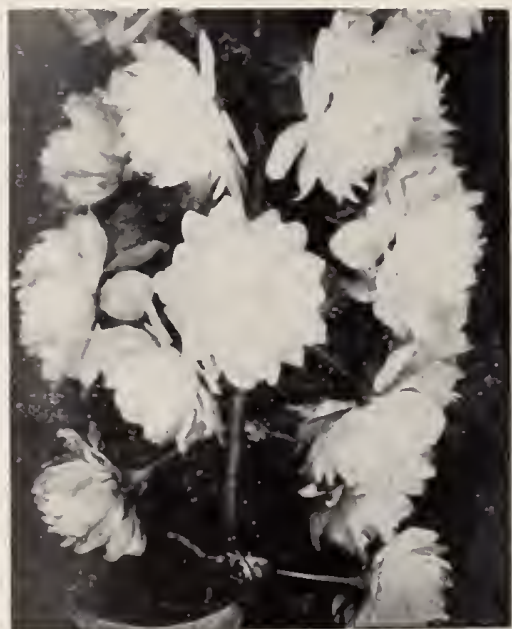

PRUNUS TRILOBA

(Double Flowering Plum)
ROSEBAY RHODODENDRON, Rhododendran maximum. BAB, $15-18$ in. $\$ 2.00$ each; $18-24$ in. $\$ 2.50$ each; $2-3 \mathrm{ft}$. $\$ 3.50$ each.

RHODORA, Rhodora canadensis. Lavender flow crs before the leaves on this native azalea of the north woods. Bushy clumps. 2-3 ft. \$2.00 each: 3.4 ft. $\$ 3.00$ each.

FATHER HUGO'S ROSE, Rosa hugonis, 18-24 in. $75 \mathrm{c}$ each.

BRIDAL WREATH, Spiraea prunifalia. I8.24 in. $60 \mathrm{c}$ cach; $2-3 \mathrm{ft}$. $75 \mathrm{c}$ each.

THUNBERG SPIREA, Spiraea thunbergi. 3.t ft. $75 \mathrm{c}$ each.

VANHOUTTE SPIREA, Spiraea zanhousei. $2-3 \mathrm{fc}$. $75 \mathrm{c}$ each.

WHITE SNOWBERRY, Sympharicarpos racemasus. 2-3 ft. $60 \mathrm{c}$ each.

CHIVESE LILAC, Syringa chinensis. 2-3 fe. 75 c each.

WHITE TREE LIL $\perp C$, Syringa japonica. $4.5 \mathrm{fc}$ $\$ 1.50$ each.

HU.VGARIAN LILAC, Syringa jasikaea. $2.3 \mathrm{ft}$. $\$ 1.00$ each.

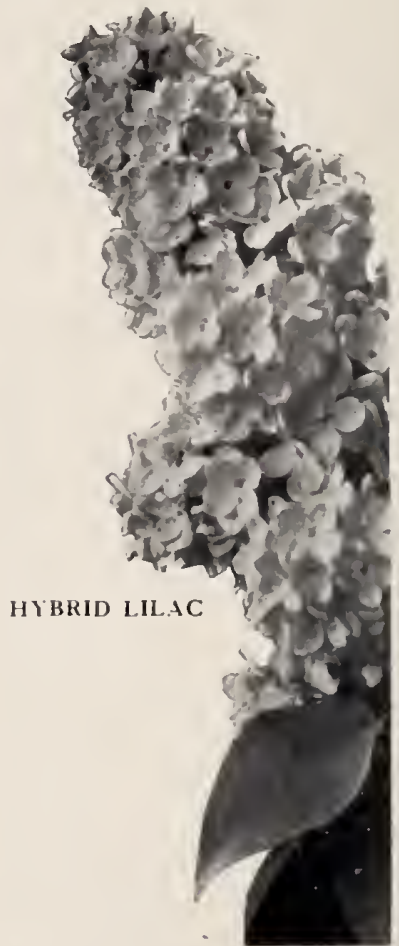

See Price Chart on page 3 if you are ordering more than one plant of a variety. 
LATE LILAC, Syringa villosa. 2-3 ft. $75 \mathrm{c}$ cach. COMIION I'URPLE IILAC, Syringa rulgaris. $18.24 \mathrm{in} .60 \mathrm{c}$ each; $2.3 \mathrm{ft} .75 \mathrm{c}$ cach.

COMMON WHITE I.ILAC, Syringa vulgaris alba. $2-3$ it. $75 \mathrm{c}$ cach.

LOWBUSII BLUEBERRY, Iaccininm pennsyl. zanicmm. Sods approximately 10 in. square. $60 \mathrm{c}$ each.

MAYFI.OWER VIBURNUM, Tiburum carlesi. BS.B. $18-24$ in. $\$ 2.50$ each.

ARROW.WOOL, Vibmrmm dentalmm. $3 \mathrm{ft}, 75 \mathrm{c}$ each.

\$NOW WEIGILLA, Heigela randida. $+\mathrm{ft} . \$ 1.50$ each.

CRIMSON WIEIGLLA, "feigela floribunda. 2-3 ft. $75 \mathrm{c}$ each.

ADAM'S NEEDLE, Yucca filamensosa. Heavy clumps. $50 \mathrm{c}$ each.

Many other varicties and sizes in lots too small to be included in this catalog. I.k us about any in which you are interested.

\section{FRENCH HYBRHD LILACS}

1 collection of these colorful, named hybrid Lilacs makes an especially attractive border. In the following list " $\mathrm{S}$ " means "single" and "D," double flowers.

Except as noted otherwise, all varieties in this list are available 2 to 3 feet high at $\$ 1.00$ each.

BEILE: DE NANCY. Satiny pink. D.

CHARLES JOLY. Dark purplish-red. D.

CHARLES $\mathbf{X}$. Reddish-purple. S.

ELIEN WIL.MOT. White. D.

KATIIERINE HATEMEYER. Blue. D.

LAMARTINE. Rose-mauve. S. $3.4 \mathrm{ft} . \$ 1.50$ each.

I.UDWIG SPAETH. Dark red. S.

MARIE I.EGRAYE. White. S.

MUE. CASIMIR PERIER. White. D 18.24 in. $\$ 1.00$ each.

MME. LEMOINE. White. D.

MONT BLANC. Whire. S.

PRESIDENT GREIY: Blue. D.

IVALDECK-ROUSSEAU, Rose-pink. D. 3-4 ft. $\$ 2.00$ each.

\section{HEDGE PI.ANTS}

For quantity rates consult PRICI: CII.IRT on page 3.

BARBERRY, Berberis thunbergi. 18.24 in. $35 \mathrm{c}$ each.

PRIVET, Lignstrum anurense. 2-3 ft. 30c each. PRIVIT, L. ibolinm. 2.3 ft. $30 \mathrm{c}$ each.

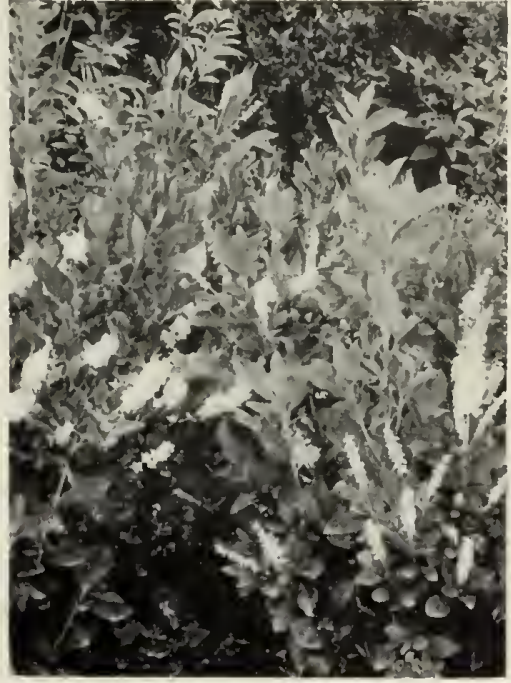

CIETHRA ALNIFOLIA

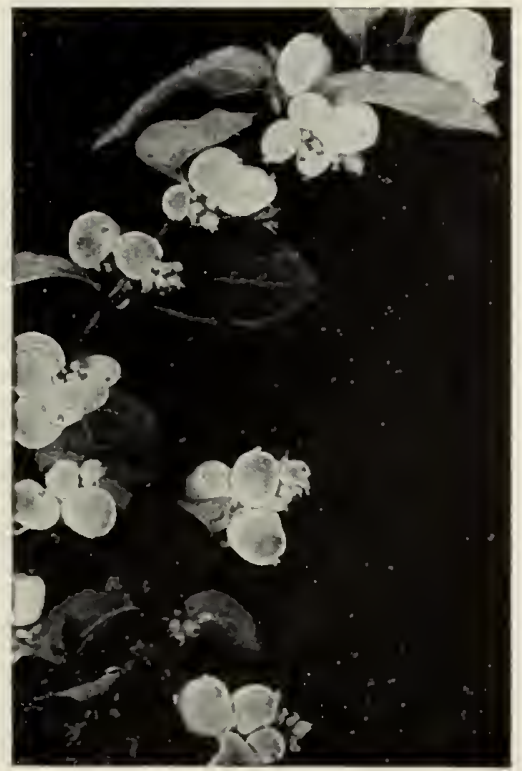

SNOWBERRY

See Price Chart on page 3 if you are ordering more than one plant of a variety. 


\section{Shade and Flowering Trees}

A pood trec is a wise investment. It improves with age. Consult the Price Chart on page 3 for reduced prices on quantities of "the same thing to the same place at the same timc." (B\&B means "Balled and Burlapped.")

WEIR CUTLEAF MAPIE, Acer dasycarpum weiri. $8.10 \mathrm{ft}$. $\$ 2.50$ each.

NORWAY MAPLE, Acer platanoides. $6.8 \mathrm{ft}$. $\$ 2.50$ each; 8.10 ft. $\$ 3.70$ each.

SCHWEDLEK MAPLE, Acer platanoides schaedleri. $6.8 \mathrm{ft}$. $\$ 3.50$ each.

SUGAR MAPLE, dcer sacrharmm. 6.8 ft. \$2.75 eacb.

HORSECHESTNUT, lesculus hippacostanum. 6.8 It. $\$ 3.00$ each.

ALLEGHENY SHADBLOW, Amelanchier laevis. $3 .+\mathrm{ft}$. $\$ 1.00$ each.

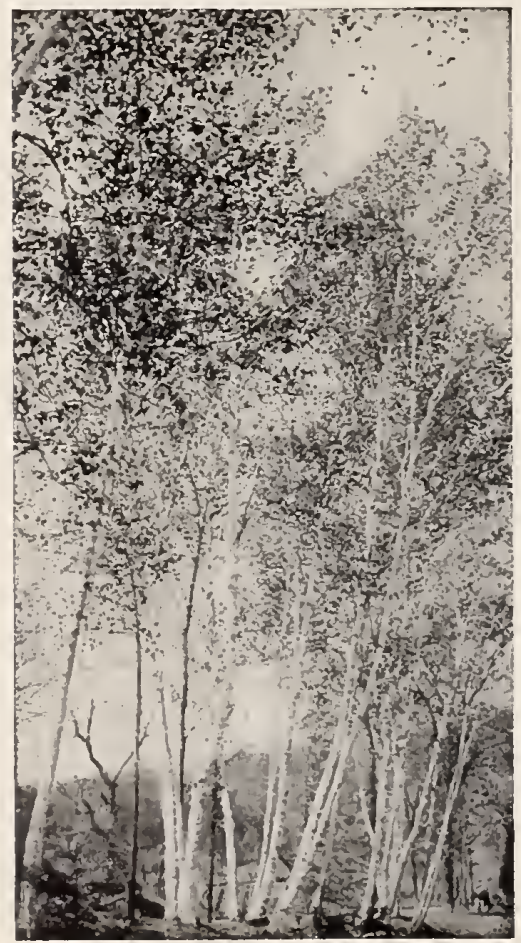

WIITE BIRCAI
CANOE or PAPEH BIRCH, Hetula papyrifera. Plant them in front of evergreens to afford their alender white trunks a foil. Transplant them onls in the early Spring, B\&B. $5.6 \mathrm{ft}$. $\$ 2.00$ each; 6.8 ft. $\$ 2.50$ each.

CHIONANTHUS VIRGINICA. (See "Flower. ing Shrubs.",

FLOWERING DOGWOOD, Cornus farida. B\&B. $3.4 \mathrm{ft}$. $\$ 2.50$ each; $4-5 \mathrm{ft}$. $\$ 3.50$ each.

PINK FLOWERING DOGWOOD, Caruus florida rubra. B\&B. 4-5 ft. $\$ 5.00$ each.

WASHINGTON HAWTHORN, Cratagks cor. dala. B\&B. 3.t ft. $\$ 2.50$ each; $4.5 \mathrm{ft} . \$ 3.00$ each.

HONEI LOCUST, Gleditsia triacanthos, 3.4 ft. $90 \mathrm{c}$ each.

GREAT SILVERBELL. Halesia tetraptera, 6-8 ft. $\$ 1.50$ each: $8.10 \mathrm{ft}$. $\$ 2.50$ each.

BUTTERNUT, Juglans cinerea. $3-f$ ft. $\$ 1.50$ each.

A.MERICAN LARCH, Larix laricina, 5-6 ft. $\$ 4.00$ each; $6-8 \mathrm{ft}$. $\$ 5.00$ each.

ARNOLD CRAB, Malus arnaldiana. 3-4 It. $\$ 2.00$ each; $4.5 \mathrm{ft}$. $\$ 2.50$ each.

CARMINE CRAB, Malus atrasanguinea. $4.5 \mathrm{ft}$. $\$ 2.50$ each; $5.6 \mathrm{ft}$. $\$ 2.75$ each.

BECHTEL CRAB. Malus ioensis bechteli. 4-5 ft. $\$ 2.50$ each; 5.6 ft. $\$ 2.75$ each.

REI)VEIN CRAB, Malus niedzreszkyana. 4-5 ft. $\$ 2.00$ each; 5-6 ft. $\$ 2.00$ each.

PARKMAN CRAB, Walus parkmani. 3-t ft. $\$ 2.00$ each.

SARGENT CKAB, Malus sareenti. 4-5 fe. $\$ 2.00$ each; $5-6 \mathrm{ft}, \$ 2.75$ each.

SOURWOOD, Oxydendrum orborem, 6-8 fe. $\$ 3.50$ each.

BAL.M-OF-GILEAD POPLAR, Papulus randi. cans. $8.10 \mathrm{ft}$. $\$ 2.50$ each.

f.OMBARD) POPLAK, Populus nigra italica. $6.8 \mathrm{ft}$. $\$ 1.25$ each; $8.10 \mathrm{ft}$. \$1.50 each.

KED OAK, Ouercus rubra. $8-10 \mathrm{ft}, \$ 4.00$ each.

WISCONSIN WEEPING; WIILOW, Salix dala. rosa (blanda). 4-6 (t. $\$ 1.50$ each.

LAUREL-LEAVED WILLOW, Salis pentandra. Bushy. 6-8 It. $\$ 2.00$ each.

AMERICAN MOUNTAIN ASH, Sarbus ameri. cana. 5.6 it. $\$ 2.00$ each; $6-8 \mathrm{ft}$. $\$ 2.50$ each.

AMIERICAN FI.M, T/mas americona. $6.8 \mathrm{ft}$. $\$ 2.00$ euch.

See Price Chart on page 3 if you are ordering more than one plant of a variets. 


\section{CONIFEROUS EVERGREENS}

Please sale yourself money and us time by using the convenient Price Chart on page ?. .ll coniferous cererecens are balled and burlapped.

lik. Abies

Balsam Fir, Balsumea $2-3$ fe. $\$ 2.00$ each; 3.4 fe. $\$ 3.50$ each.

JLNII'EK, Jusiperus

Columnar Juniper, Chinensis colmunaris. 2-3 ft. \$2.00 each.

Phtzer Juniper, Chinensis pfitzeriana. 2-3 ft. spread, $\$ 3.50$ each; $3.4 \mathrm{ft}$. spread, $\$ 4.00$ each. Pasture Juniper, Communis. $3 \cdot 4$ ft. spread. 53.50 each.

Spiny Greek Juniper, Excelsa stricta. I5-I8 in. \$I.75 each: I8.2t in. $\$ 2.00$ each.

Indorra Juniper, IJorizoutalis plumosa. 15.18 in. spread, \$I.50 each.

Veser Juniper, Squamata meyeri. 15.18 in. $\$ 2.75$ each; $18-2+\mathrm{in}, \$ 3.50$ each.

I. AKCH, Larix.

tee deciduous rees.

SPRUCE, Picea.

Blue Spruce, Pungens slanca. 21,-31; ft. $\$ 2.50$ each.

lie can supply larpe specimens of Culurado Blue and Green Spruce and Vorway Spruce lo nearby punsut?.

PINF, Pinus.

Mugho Pine, Montana mughus. 18-24 is. $\$ 2.50$ each: $2.21 / 2$ ft. $\$ 3.00$ each.

White Pine, Strobus. $2.3 \mathrm{ft}$. $\$ 2.25$ each.

I Ell, Taxus.

Spreadink Yew, Cuspidata. 15.18 in. spread $\$ 3.00$ each: 18.24 in. spread, $\$ 4.00$ each.

DWARF YEW, Cuspidata nana. 15.18 in. spread, $\$ 3.50$ each; 18.24 in. spread, $\$ 4.50$ each.

I KBORVITAE, Thuya.

Pyramidal Arborvitae, ()ccidentalis pyramidalis. $2-3 \mathrm{ft}$. $\$ 2.50 \mathrm{each}$.

Globe Arborvitae, Occidentulis woodwardi. I\$-24 in. $\$ 2.00$ each; $3-31$ ft. $\$ 3.00$ each.

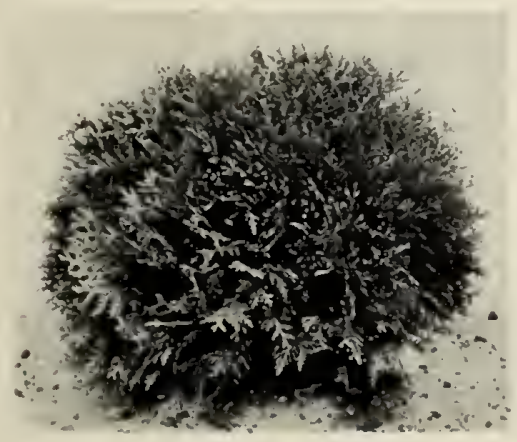

TIIUYA WOOIOW ARIMI
11EMIIOCK, Fsuga cauadensis.

18.24 in. $\$ 1.75$ each; $2.3 \mathrm{ft}$. $\$ 2.04 \mathrm{esch} ; 4.5 \mathrm{ft}$. $\$ 5.00$ each: $5-6 \mathrm{ft}, \$ 7.00$ each.

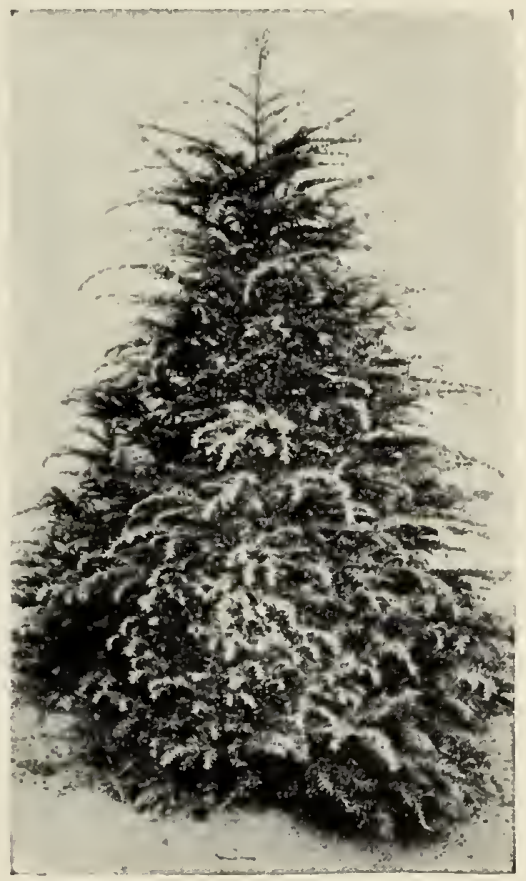

TSUGA CANAIENSIS

VINES strong Plants

AKEBIA QUINATA. I very few al 75 c each. HOODBINE, Ampelopsis quinquefolia. 45c each. ENGEIMANN CREEPER, Ampelopsis quinquifolia engelmanni. 60c each.

IUTCIMAN'S PIPE, 1ristolochia sipho. $90 \mathrm{c}$ each.

TRUMIPT CREFPI:R, Bignonia radicans, $60 \mathrm{c}$ each.

ORIENTAI. BITTERSWEIT, Celastros orbiculatus. $60 \mathrm{c}$ each.

EVERGREEN WINTERCRFI:PER, Inonyms radicans. $60 \mathrm{c}$ each.

CHINESE WISTERIA, U'isteria simensis. $75 \mathrm{c}$ each.

See Price Chart on page 3 if you are ordering more than one plant of a variety. 


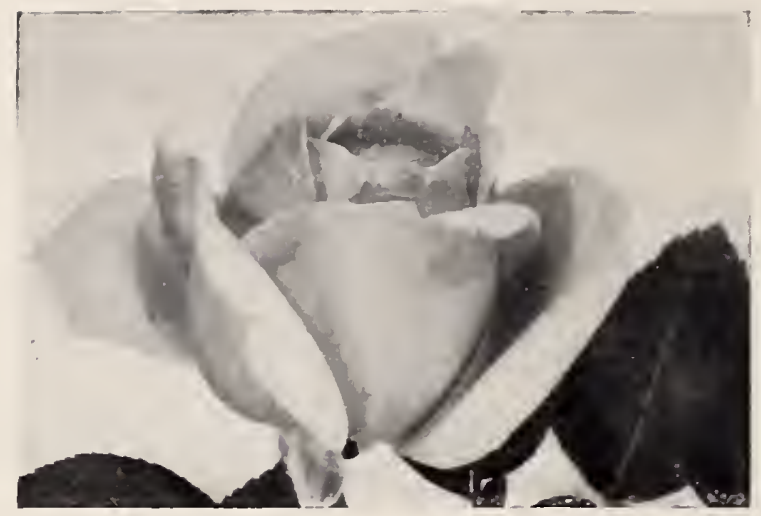

ROSES for BEAUTY

\section{OLD FASHIONED SHRUBBY ROSES}

HARRISON'S YELLOW. Yellow, 75c each. FATHER HUGO'S ROSE, Roso hugonis, Yellow, 75 c each.

HENRY MARTIN MOSS ROSE. Dark red (large plants). $\$ 1.00$ each.

RUGOSA ROSE. Red or white. 60e each. AGNES, Rugosa hybrid. lellow. 70c each.

SIR THOMAS LIPTON, Rug. hyb. White (large plants). $\$ 1.00$ each.

\section{CLIMBING ROSES}

$80 \mathrm{e}$ each

SILVER MOON. White.

PAUL'S SCARLET. Red.

WHITE DOROTHY PERKINS. White.

\section{EVERBLOOMING CLIMBERS}

BLAZE (Plant Patent Xo. 10). Brilliant scarlet. $\$ 1.00$ each.

NEW DAWN (Plant Patent No. 1). Appleblossont pink. \$I.50 each.

DUBLOONS (Plant Patent No. 152). Golden yellow. \$1.00 each.

\section{TEN HARDY FAVORITES}

Here are ten hybrid bedding roses which have been carefully selected for their beauty. variation in coloring, extreme hardiness and healthiness.

Price: $75 \mathrm{c}$ each. (Add $15 \mathrm{c}$ for potting after May 1st.)

RADIANCE, Brilliant carmine-pink with salmonpink and yellow shadlings. This and Red Radiance are the most easily grown and most satisfactory Hybrid Teas.

RED RADIA.NCE. Bright cerise-RED, particularly splendid in the Fall.

FRAU KARL DRUSCHKI. The best WIITTE. rose. Many newer. but none better.

CALEDONIA. Large WHITE druble fiower. lery hardy. Slizhtly fragrant.

MRS. PIERRE S. DU PONT. Golden l'ELLOW with reddish tints in the bud. Tle easiest to grow of the difficult yellow varietics. Outstandingly beautiful.

JOANNA HILL. Fragrant, clear YELLOW shading to orange in the fully expanded blossom.

CONDESSA DE SASTAGO. Golden Y'ELLOW petals are lined with reddish copper. A very vigorous, healthy plant.

BRIARCLIFF, Deep rose-PINK, with liphter tints. A moderately fragrant, very" popular outdoor and greenhouse ro e.

E. G. ItILL. I rich, deep red of fine fragrance.

MRS. SAM MeGREDY. Copper, scarlet and orange. A brilliant flower on vigurous, healthy buslies.

\section{GARIEEN OF ROSES}

All ten of the above varieties (one of each) lor only $\$ 6.00$. 


\section{VEGETABLE PLANTS}

Orders will be filled in the sequence received as long as the supply of plants lasts. Plants will be sent at the proper stage and time for transplanting. The varieties are espectally recommended for New Eingland.

\section{Prices: 50e per dozen}

CABB.AGE, EARIY, Golden Acre.

CABBAGE, IATE. Penn State Balthead.

CAULIFLOWER. Early Snowball.

LETTUCE, HEAD. New York I2.

I.ETTUCF, I.EAF or LOOSE-IIEAD, Black Seeded sinuparn.

PEPPER. Ruby King.

TOMATOIS. John Baer, Earliana, Marglobe and sirikerlate.
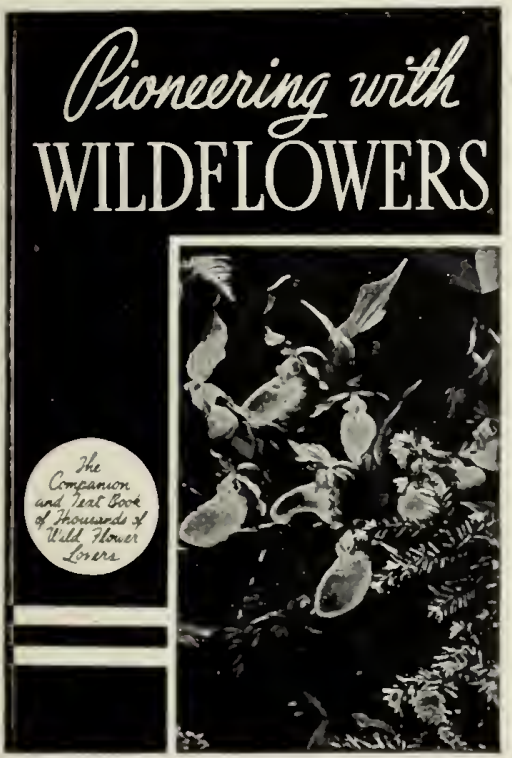

PIONEERING WITH WILDFLOWERS By GEORGE D. AIKEN. $\$ 2.00$ postpaid

This book still holds its place as the best scller amonf wildflower books. It not only helps you to identify the wildflowers, tells where they grow, but also how they may be made to grow on your own home srounds.

Beautifully printed and bound, with over a hundred excellent illustrations.
PIONEERING WITH FRUITS AND BERRIES

By GEORGE D. AIKEN

P'oneering with Fruits and Berries deals in simple facts concernine Fruit Trees, Raspberries, l-paragus, Grapes, what to do, how to do it and when. I farmer and a nurseryman, Mr. Aiken is well capacitated to handle this large subject in the understandable way in which it is done. He has told you what to do with the trees as they come from the nursery, how to care for then during the firt, very important year on your land. He tells of the pirates, the insect pests, which will come sneaking in to destroy and how to make them walk their own planks.

We can unlesitatingly recommend Pioneering with Fruits and Berries as being exactly as important and unique in its field as has been Pionecring with Wildforers. The price is $\$ 2.00$ postpaid anywhere.

\section{ANNUAL AND BEIDING FLOWER. ING PLANTS}

\section{BEGONIAS CAIENDUIAS GHRANIUIS \\ PETUNIAS SWEET WILLIAM ZINNIAS I.E.MON VERBENA, etc. \\ lints of varieties and prices will be sent on} request.

\section{BEAR PAW POPCORN}

1942 crop. On the cob (except into California where only shelled corn is admitted). 8 pounds for $\$ 1.00$.

\section{MAPIE SYRUP}

1963 crop as soon as ready and av long as it lasts, \$3.35 per gallon.

\section{PINE NEEDI.ES}

For mukching many of the acid-soil Wildhowers. especially Trailing Arbutus. Partially decomposed. Two-bushel bag for $\$ 1.50$. 



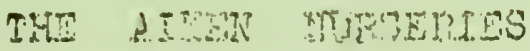

\section{Nane $\operatorname{Lin}$,}

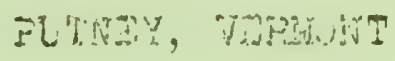

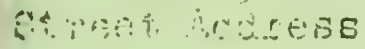

Lost $0 \leq 103$

State

Zuntules Orfine

Ship on or gind

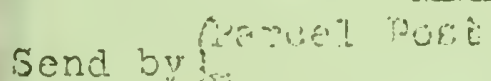

terpesis drite_ 194_ Aint. enclosed

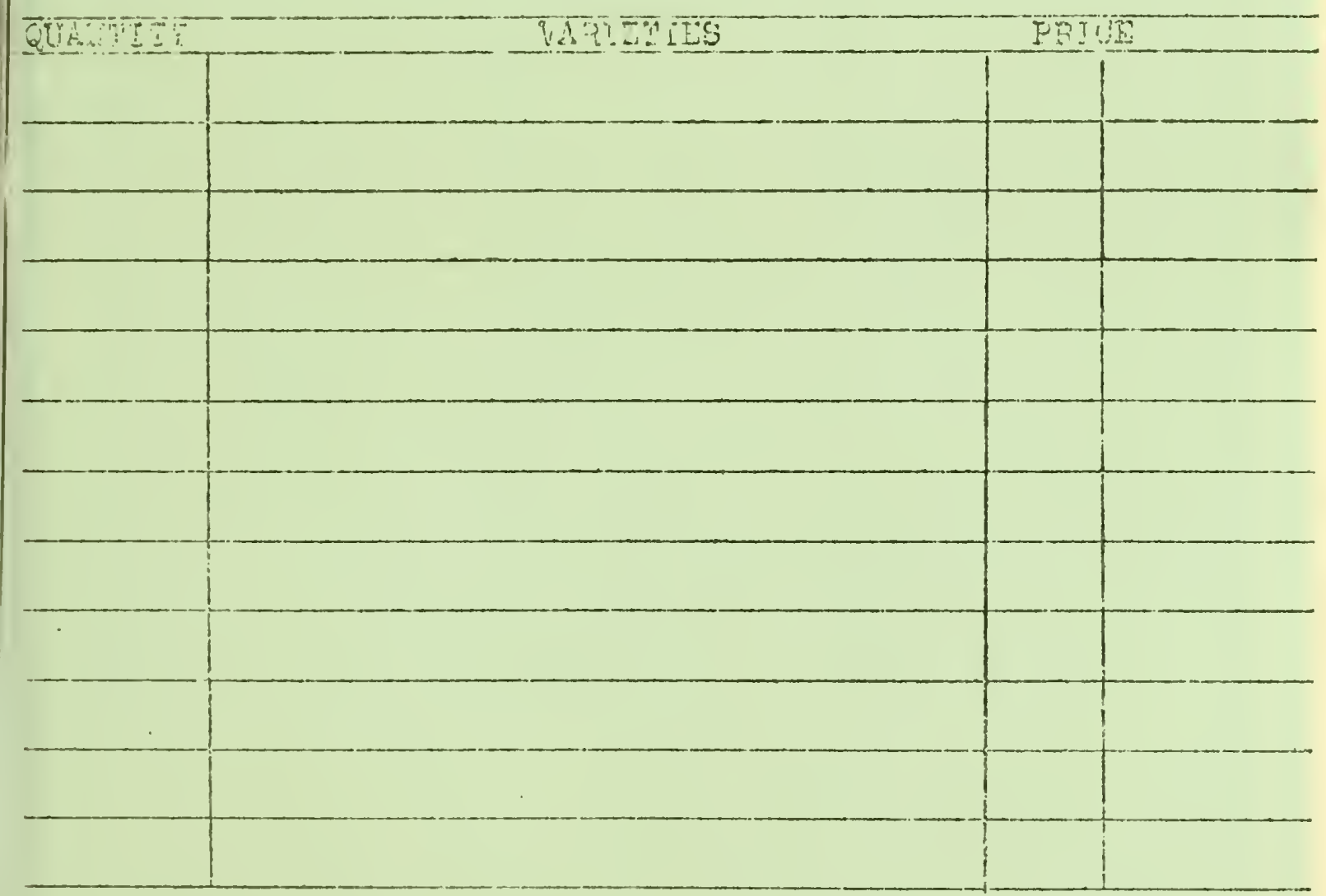

Mease son quantity fuIl name, size and orive of ean ibern 


\title{
THE AIKEN NURSERIES PUTNEY, VERMONT
}

\author{
s? \\ "Grown in Vermont, It's Hardy" \\ 约
}

